Ankara Üniversitesi

SBF Dergisi,

Araştırma Makalesi

Cilt 75, No.4, 2020, s. 1299-1346

DOI: 10.33630/ausbf.591234

\title{
YOKSUNLUK ENDEKSINI ETKILEYEN FAKTÖRLERIN EKONOMETRIK ANALizi
}

\author{
Doç. Dr. Mehmet Zanbak \\ Akdeniz Üniversitesi \\ İktisadi ve İdari Bilimler Fakültesi \\ ORCID: 0000-0002-9838-9063
}

\section{Öz}

Yoksulluğu, gelir yanında sosyoekonomik değişkenlerin de dâhil edildiği bir düzlemde ele alan bu çalıșma, bireylerin yoksunluğunu etkileyen faktörlerin ortaya çıkarılmasını hedeflemektedir. Bu amaçla ilk aşamada 2011 yılında Mersin ve Erzurum illerinde uygulanan alan araştırmasının verileri kullanılarak kent bazlı yoksunluk endeksi hesaplanmış, sonrasında ise en küçük kareler yöntemi ile bu endeksi etkileyen faktörlerin yönü ve şiddeti tespit edilmiştir.

$\mathrm{Bu}$ çerçevede endeks ortalamaları Mersin'de yaşanan yoksunluğun Erzurum'un üzerinde olduğunu göstermektedir. Ayrıca bireylerin yoksunluklarını ve bu yolla da yoksulluklarını arttıran faktörlerin başında; kadınların yevmiyeli, kendi hesabına düzensiz işlerde ve işçi statüsünde çalışmaları ile okula gitmemiş olmaları; erkeklerin ise okula gitmemiş olmaları ile başta etnik nedenler olmak üzere kendisine önyargılı davranıldığına inanmaları gösterilebilir. Aynı kişilerin refah seviyelerini arttırmalarına yardımcı olabilecek faktörlerin ilk sıralarında ise, kadınların üniversite eğitimi almıș olmaları, erkeklerin memur statüsünde çalışıyor olmaları yer almaktadır.

Anahtar Sözcükler: Yoksunluk, Yoksulluk, Yoksunluk endeksi, Yatay-kesit analiz

\section{Econometric Analysis of the Factors Affecting Deprivation Index}

\section{Abstract}

This study, addressing poverty as a function of socioeconomic variables besides income, aims at revealing factors that affect individual's deprivation. With this aim, by using the data set obtained from the field survey carried out in Mersin and Erzurum provinces in 2011, at the first step city-based deprivation index was calculated and then by employing least-squares method the size and direction of the variables that affect deprivation index was determined.

The average index values show that deprivation experienced in Mersin is above than it is in Erzurum. The main factors that affect individuals' deprivation and hence their poverty are: women's working in irregular jobs as paid workers and on daily-wage; their low education level; men's low level of education; ethnic origin and individual's belief that people are prejudicial towards them. Factors that help to improve individuals' welfare are found to be women's having a university degree and men's working as a civil servant.

Keywords: Deprivation, Poverty, Deprivation index, Cross-section analysis

* Makale geliş tarihi: 20.12.2018

Makale kabul tarihi: 24.04.2019

Erken görünüm tarihi: 12.07.2019 


\section{Yoksunluk Endeksini Etkileyen Faktörlerin Ekonometrik Analizi ${ }^{1}$}

\section{Giriş}

Yoksulluğu yetenekler yaklaşımını temel alarak ve çok boyutlu bir bakış açısıyla ele alan bu çalışmanın başlıca amacı, gelir yanında diğer sosyoekonomik değişkenlerin de dâhil edildiği bir çerçevede, Mersin ve Erzurum illerinin yoksunluğunu etkileyen faktörleri ortaya koymaktır. Kabul edilebilir bir hayat düzeyine ulaşmak için gerekli "yeteneklere erişememe" olarak tanımlanabilen yoksunluk üzerinde oldukça fazla faktör etkilidir ki bu çalışmada da söz konusu etkilerin şiddetinin ve yönünün tespit edilmesi planlanmaktadır. Örneklem olarak Mersin ve Erzurum'un seçilme nedeni olarak; Türkiye İstatistik Kurumu (TÜİK) tarafindan 2006 yılı sonrasında yapılan yoksulluk hesaplamalarında bu iki kentin sırasıyla iyileşme ve kötüleşme yaşayan kentlerin arasında yer alıyor olmaları gösterilebilir. Bu nedenle, parasal yaklaşımla yoksulluk oranları farklı kutuplara ilerleyen iki kentin, yoksunluğuna etki eden unsurları belirlemek, bu çalışmanın amaçları arasındadır. Ayrıca dinamik bir yapıya sahip olan ve gelişme sürecine yön veren sosyoekonomik faktörlerin farklı yoğunluklardaki dağılımının, bölgelerarası gelişmişlik farklılıklarının temel nedeni olarak ortaya çıkması, Mersin ve Erzurum'un ise söz konusu farklılığı en iyi şekilde yansitabilmeleri bu illerin seçilmelerinin bir başka nedenidir.

Bireylerin yoksunluk şiddetinin ortaya çıkarılabilmesi adına başlangıçta bir endeks hesaplaması yapılabilir. Bu doğrultuda çalışmada her birey için öncelikle kısmi, sonrasında ise tüm boyutların kapsandığı bir yaklaşımla toplam yoksunluk endeksinin elde edilme yöntemleri şekilsel destekli olarak anlatılmış ve cinsiyete göre bireylerin endekslerini etkileyen faktörlerin ön plana çıkarılması düşünülmüştür. Bir başka anlatımla çalışmada Mersin ve Erzurum illerinin kentsel alanlarında yaşayan bireylerin cinsiyetlerine göre yoksunluk endeksleri ve bu endeksi etkileyen faktörlerin belirlenmesi hedeflenmektedir. Uygulanan ekonometrik analiz için gerekli olan veri seti 2011 yılında yapılan

1 Bu çalışma, TÜBİTAK (Proje No: 110K445) ile Akdeniz Üniversitesi Bilimsel Araştırma Projeleri Koordinasyon Birimi (Proje No: 2011.03.0107.003) tarafindan desteklenmiş ve yazarın doktora tezi (Zanbak, 2014) esas alınarak hazırlanmıştır. 
ankete dayandırılmış ve yoksunluk endeksini hesaplamak için 8 boyuttan 58 gösterge $^{2}$, bu endeksi belirleyen faktörleri saptayabilmek için ise 6 boyuttan 72 farklı gösterge belirlenmiştir. Bu aşamada gösterge (değişken) sayısı faktör analizi yapılarak 67'ye düşürülmüş ve analiz bu 67 değişken ile yapılmıştır ${ }^{3}$. Endeksi etkileyen faktörlerin tespiti aşamasında modele, endeksin hesaplanmasında kullanılan göstergeler dahil edilmemiştir. Bu nedenle endeksin hesaplanmasında 58 gösterge kullanılmaktayken, etkinin ortaya çıkarılmasında farkl1 67 göstergeye başvurulmuştur.

$\mathrm{Bu}$ çerçevede çalışmanın ilk bölümünde yoksulluk ve yoksunluk iliş̧isi ele alınmış, devamında ise konu ile ilgili literatür özetine yer verilmiştir. Üçüncü bölümde yoksunluk endeksine ve endeksin hesaplama yöntemine değinilirken, çalışmanın dördüncü başlığı altında ampirik analiz yapılmış, Mersin ve Erzurum'un yoksunluk endeksine etki eden faktörler en küçük kareler yöntemi ile tahmin edilmiştir. Çalışmanın sonuç kısmında ise genel bir değerlendirme yapılmış ve politika önermeleri sunulmuştur. Bu noktada vurgulanması gereken bir husus, ulusal literatür incelendiğinde konunun henüz ele alınan boyutta işlenmemiş olduğu ve bu nedenle de önemli bir boşluğu doldurulacağına inanıldığıdır. Ayrıca çalışmanın özellikle mikro ölçekli politikaların üretilmesi ve önceliklerin tespit edilmesi bakımından politika yapıcılara fikir verebileceği düşünülmektedir.

\section{Yoksunluk - Yoksulluk İlişkisi}

Sen (1976; 2004) yoksulluğu, insanca bir hayat yaşayabilmek için gerekli olan temel yeteneklerden yoksun olma durumu olarak tanımlamakta, yoksulların gelir veya fayda yerine, bireysel özgürlüklerin ön plana tutulduğu bir yaklaşımla tespit edilmesi gerektiğini vurgulamaktadır. Yoksun olma durumu, herhangi bir olguya ulaşamama, elde edememe, daha net bir ifade ile bir yeteneğe ulaşmadaki eksiklik olarak ortaya çıkmaktadır. Bu çerçevede Sen $(1982 ; 1999)$ yoksulluğu "genel kabul gören bir hayatın gerektirdiği asgari ihtiyaçlar için gerekli gelir düzeyine sahip olmamak" şeklinde tanımlayan geleneksel görüşlerin aksine,

$2 \mathrm{Bu}$ çalışmada yer alan boyut ve göstergeler ile yoksunluk şartları sırasıyla EK 2 ve EK 3 'te sunulmuştur. Çalışma, yoksulluk ve yoksunluk kavramını, yetenek yaklaşımı temelinde çok boyutlu bakış açısıyla ele alarak, yoksulluğun kayıp boyutlarına odaklanmaktadır. Bir başka ifadeyle kayıp boyutların da dâhil edildiği çok boyutlu bir yoksulluk analizinin temel amacı, kişinin yaşam standartlarının nihai durumunun tespit edilmesi ve geliştirilmesi için politika önerilerinin sunulmasıdır. Bu nedenle çalışmada, salt klasik parasal göstergeler yerine, Alkire ve Foster (2007) ile Alkire'in (2007) yoksulluğun kayıp boyutları olarak nitelendirdikleri boyut ve göstergeler kullanılmıştır. Söz konusu boyutlar; İstihdam-İş Yeri Güvenliği, Gelir, Sağllk, Güçlenme Utanma/ Dışlanmışlık Hissetmeden Yer Alma, Yaşamsal Anlam ve Değer, Fiziksel Güvenlik ile Hanenin Sosyo-Ekonomik Yapısı şeklinde sıralanabilir.

3 Faktör analizinde Tatlıdil'in (2002) çalışmasından yararlanılmıştır. 
insanların "ne yapıp yapamadikları ve ne olup olamadiklarına" bakılmas gerektiğini savunmaktadır. Bu paralelde yoksunluk, standart yoksulluk ölçütü olan gelir düzeyi yerine, kabul edilebilir bir hayat düzeyine ulaşmak için gerekli temel yeteneklere erişememe olarak da tanımlanabilmektedir.

Alkire ve Foster (2007; 2011a; 2011b) Sen'in yetenekler yaklaşımını temel alarak tanımladıkları yoksulluğun gelir ve tüketim harcamalarını kapsayan parasal göstergelerden bağımsız düşünülmesi gerektiğini belirtirken, "bir kişinin yoksul olarak kabul edilebilmesi için birden fazla boyutta yoksun olması" gerektiğini belirtmiştir. Kişinin yoksun olmasını ise herhangi bir boyutta istenen ya da olmast gereken ortalama durumun elde edilememesi şeklinde tanımlamışlardır. Bireyin ve dolayısıyla hanenin gelir seviyesinin belirli düzeyin altında olması, sağlık durumlarının kötü olması, çalıştıkları işte kendini mutlu hissetmezken aynı zamanda ișvereninden ya da amirinden baskı görüyor olması, çalışma koşullarının güvenli olmaması, bireyin haneyi ilgilendiren karar mekanizmalarına dahil olamaması ve kendini özgür hissedememesi bu alanlardaki yoksunluklarını ifade etmektedir. Ayrıca içinde bulunduğu sosyoekonomik durumdan utanan, kendini dışlanmış ve küçük düşmüş hisseden, sahip olduğu maddi/manevi değerlerle mutlu olmayan, hayata karamsarlıkla bakan, yaşadığı ortamda kendini güvende hissedemeyen, her an kendisinin ya da aile fertlerinin başına bir şiddet olayının geleceğine inanan, yaşadığı hanenin sosyoekonomik yapısı yetersiz olan kişiler de yoksun bireyler olarak gösterilebilir. Parasal göstergeler yanında sosyal göstergelerin de önem kazandığı bu yaklaşıma göre gelir seviyesi düşük, ailesinde boşanmış ve engelli bireylerin olduğu, sosyoekonomik statüsü göreli daha düşük olan dezavantajlı grupların sosyal göstergelerde yoksunluk yaşama olasılıkları daha fazladır.

\section{Literatür Özeti}

Hem ulusal hem de uluslararası alanda parasal yoksulluk ölçümlerinin eksikliğini giderebilmek amacıyla özellikle uluslararası araştırmacılar tarafindan yeni yaklaşımlar ortaya atılmış ve bu yaklaşımlarla yoksunluk ve dolayısıyla yoksulluk, yaşamın tüm boyutlarını ele alınarak ortaya çıkarılmaya çalışılmıştır. $\mathrm{Bu}$ yaklaşımların parasal yöntemlerden ayrışmasını sağlayan ilk araştırmacılar arasında Sen $(1976 ; 1983 ; 1997 ; 1999 ; 2004)$ ve Foster vd.'nin (1984) çalışmaları sıralanabilir. Bu çalışmalar, iktisat disiplinindeki dar insan görüşüne karşı çıkarak yoksulluğun salt gelire bağlı olmadığını, iyi yaşama dair olan her şeyin yoksunluk ölçümünde değerlendirilmesi gerektiğini vurgulamaktadır. Foster vd. (1984), literatüre kazandırdıkları FGT yaklaşımı (karesi alınmış düzeltilmiş yoksulluk açı ̆̆ı) temelli ilk uygulamalarından birisini, Kenya'nın başkenti Nairobi'de 1970 yılında 1416 hanede (3987 kişi) yapılan anket verileriyle gerçekleştirmiştir. Hanedeki yetişkinlerin gelir, eğitim, iş, medeni hal ve diğer 
karakteristik özelliklerinin ortaya çıkarılması için uygulanan bu anket verileriyle yapılan analiz sonuçlarına göre, 1970 yılı için yetişkin başına yıllık yoksulluk sınırı 515 Kenya para birimidir. Bu sınır göz önüne alındığında yoksulluk oranı 0,13 iken, FGT endeksi 0,056 olmuştur.

$\mathrm{Bu}$ çalışmada hesaplanan yoksunluk endeksinin temelini de oluşturan kaynaklardan birisi Macculi'ye (2009) aittir. Araştırmacı çalışmasında 19992007 yılları arasında İsviçre'deki refah düzeyini hanehalkı panel verileriyle incelemiş ve bunu yaparken de yoksulluğu çok boyutlu bakış açısıyla ele almıştır. Bir diğer ifadeyle yoksulluğa parasal göstergelerden ziyade, özellikle herhangi bir unsura sahip olma ya da onu gerçekleştirebilme odağından yaklaşan araştırmacı; temel yoksunluk, dayanıklı tüketim mallarına sahip olma, hanenin fiziksel koşulları, yaşam stili ya da sosyal dışlanma, finansal yoksunluk ve yaşamsal memnuniyet gibi 6 temel boyut ve bunları temsilen 27 göstergeyi kullanarak çok boyutlu bir analiz gerçekleştirmiştir. Araştırmacının hesapladığ yoksunluk endeksi bulgularına göre, İsviçre'de yaşayan bireylerin en şiddetli yoksunluk yaşadığı boyut hanenin fiziksel koşulları olmuştur. Hanenin fiziksel özellikleri; büyüklügü̈; ısınma şekli; çevresel ses düzeyi; nüfusun ve trafiğin yoğunluğu ile sanayi bölgelerine yakınlık ve güvenlik şartları bu boyutu temsil eden başlıca göstergelerdir. Ayrıca yabancıların yerlilere, çalışmayanların ise istihdam edilenlere göre daha fazla yoksunluk yaşadığı ve sosyal olarak dışlanmış olduğu, bu çalışmanın temel bulguları arasındadır. Yoksunluk endeksi bağlamında yapılan bir diğer çalışma da Kroll vd. (2017) tarafından kaleme alınmıştır. Almanya'da 1998-2015 yılları arasındaki geçen süreçte bölgesel anlamda sosyoekonomik yoksunluğun incelendiği çalışmada; eşit ağırlıklı iş, eğitim ve gelire ilişkin göstergeler kullanılmıştır. Bunlara ek olarak beklenen ömür, doğum ve ölüm oranları, beslenme, sağlık imkanlarına erişim, obezite, sigara kullanımı, boş zaman gibi göstergelerin de dahil edildiği sağlı boyutu, çalışmada ele alınan bir diğer başlık olmuştur. Araştırma sonunda özellikle sağlık alanında elde edilen endeks değerlerinin bölgeler arasından farklılaştığı tespit edilmiş ve politika yapıcılara öncelikli olarak sağlık alanındaki eşitsizliğin giderilmesi önerilmiştir.

Çok boyutlu yoksunluk endeksinin hesaplandığı bir diğer çalışmada (World Bank, 2017) Avrupa Birliği üyesi Hırvatistan'ın durumu araştırma konusu edilmiştir. Veri seti olarak 2011-2015 dönemindeki anketlerden yararlanıldığ ve temel olarak ekonomi, sosyal ve hizmetlere erişim boyutlarındaki yoksunluğun analiz edildiği bu çalışmada 8 alt boyut ve 31 gösterge hesaplamaya dahil edilmiştir. Analiz sonucunda özellikle ekonomi boyutunu temsil eden göstergelerdeki yoksunluğun öne çıktığı vurgulanmıştır. Yoksulluk hesaplamalarına farklı bir bakış getiren çalışmaların en önemlilerinden birisi de Bourguignon ve Chakravarty (2003)'tür. Çalışmada parasal yaklaşımlara alternatif olarak, her boyutun kendi sınırının olduğu çok 
boyutlu bir hesaplama yöntemi önerilmektedir. Bunun için öncelikle boyutların ve sonrasında da bu boyutların yoksunluk sınırlarının tespit edilmesi gerektiği belirtilmektedir. Yoksunluğu belirlemede kullanılan yöntem, kişinin sahip olduğu değerin yoksunluk sınırının altında olup olmamasının tespiti şeklindedir. $\mathrm{Bu}$ çalışmada yoksunluk endeksi formunun oluşturulması aşamasında temel alınan çalışmalardan olan Bourguignon ve Chakravarty (2003), 1980'li yıllardaki Brezilya'nın kırsal alanlarındaki çok boyutlu yoksulluğu tespit etmeyi amaçlamıştır. Hesaplamayı çok boyutlu hale getirmek için gelir ve eğitim göstergelerini kullanan araştırmacılara göre 1981-1987 y1lları arasında gelir yoksulluğu artarken, buna karşın eğitim yoksulluğu azalmaktadır. Yoksunluğu ele alış biçimi parasal yaklaşımlardan ayrılan ve literatürdeki yerini "AF Yaklaşımı" olarak alan bir başka ölçüm yöntemi de Alkire ve Foster'ın (2007, 2011a) çalışmalarında yer almaktadır. Araştırmacılar, hesaplamalarını 2000 yılında Endonezya'da (2000 hane, 19.397 fert), 2004 yılında ABD'de (45.884 fert) uygulanan anketlerden elde edilen veriler 1 şı̆̆ında gerçekleştirmiştir. Endonezya için yapılan hesaplama sonucunda en az yoksunluk yaşanan boyutun nüfusun \%17,1'i ile sağlık boyutu, en fazla yoksunluğun yaşandığ nüfusun \%43,9'u ile temiz içme suyu boyutu olduğu anlaşılmaktadır.

Chakravarty vd.'nin (2008) küresel anlamda hazırlanan en kapsamlı yoksulluk araştırmalardan olan ve 1993-2002 dönemi için 164 ülkenin toplam nüfusundan oluşan örneklemin çok boyutlu yoksulluğunu inceledikleri çalışmalarında ise; kişi başına düşen milli gelir, yaşam beklentisi ile okuma yazma oranı göstergeleri ele alınmış ve yoksunluk endeksinin yıllar itibariyle değişiminin ortaya çıkarılması hedeflenmiştir. Bu çalışmanın bir diğer amacı, yoksunluk yaşayanlar arasındaki eşitsizlik ile yoksulluk açığı oranının ortaya çıkarılmasıdır. Yapılan analiz sonucunda dönem başında 44 olan kişi başına düşen yurtiçi hasıla yoksunu ülke sayısı, dönemin sonuna gelindiğinde 38 'e, 40 olan okuma yazma göstergesindeki yoksun ülke sayısı ise 28 'e gerilemiştir. Battiston vd. (2009) 1992-2006 dönemi için 6 Latin Amerika ülkesini ele alarak 6 boyutlu çalışmalarında boyut olarak gelir, okullaşma, hanehalkı reisinin eğitim düzeyi, tuvalet/kanalizasyon, su ve barınmayı eşit ağırlıklandırarak ölçüme dahil etmiş ve sonraki aşamada her bir boyut ile bunları temsil eden göstergelerin yoksunluk sınırlarını belirlemişlerdir. Bu çalışmanın sonuçlarına göre, El Salvador 1992-2006 döneminde yoksunluğu en yoğun yaşayan ülke olurken, bunu sırasıyla Meksika, Brezilya, Şili, Arjantin ve Uruguay takip etmiştir.

Konu ile ilgili dünya ölçeğindeki en kapsamlı çalışmalardan birisi de Alkire ve Santos'un (2010) 2000-2008 yılları arasındaki veriler 1şı̆̆ında 104 gelişmekte olan ülkeyi içine alan çalışmasıdır. Dünya nüfusunun 2007 verileriyle yaklaşık \%78'ine karşılık gelen bu örneklemin, yoksunlukların ortaya çıkarılması, bir anlamda küresel yoksulluğun yansitılması ve bir yoksulluk haritasının oluşturulması bakımından önem arz ettiği söylenebilir. Yoksunluk 
şiddetinin ölçülmesinde öncü çalışmalardan birisi olan Alkire ve Foster (2011b), yoksulluğu sadece parasal göstergelerle yansıtmanın yetersizliğini ve bu nedenle hesaplamaya yoksulluğun kayıp boyutlarının da dahil edilmesi gerektiğini vurgulamıştır. Çalışmada, ülkeler arası bir karşılaştırmayı da yansıtmak amaciyla, 2006-2007 yıllarında yapılan anket verileriyle, Hindistan eyaleti olan Madhya Pradesh, Afrika Kıtası ülkelerinden Demokratik Kongo Cumhuriyeti'ni ele almış ve bu ülkelerdeki yoksulluğu Alkire ve Santos'un (2010) çalışmalarında kullandıkları boyut ve göstergeler aracılığıyla ölçmeye çalışmıştır.

Yoksunluğu ve dolayısıyla yoksulluğu Türkiye ölçeğinde parasal yaklaşımların dışında, farklı bir bakış açısıyla ele alan Akder (2000), 1990-1996 dönemi verileriyle örneklemini okuryazarlık derecesi, doğumda yaşam beklentisi, ortalama nüfus büyüklüğü ve gelir göstergeleri kırsallık derecesi ile insani gelişme düzeyine göre gruplandırmış ve analiz etmiştir. Analiz sonuçlarına bölgesel açıdan bakıldığında yüksek düzey insani gelişmenin, Marmara Bölgesi ve Ege Bölgesi’nde yoğunlaştığı görülürken, düşük düzey insani gelişmenin hem Güneydoğu Anadolu hem de Doğu Anadolu Bölgesi'nde egemen olduğu ortaya çıkmaktadır. Yoksunluğa alternatif hesaplama yöntemleriyle yaklaşan bir diğer çalışma olan Gürsel vd.'de (2013), 2005-2010 döneminde, Türkiye gibi bölgeler arası gelir eşitsizliğinin yüksek olduğu ülkelerde yaşanan yoksunluğun gerçekçi bir şekilde saptanamadığı vurgulanmaktadır. Parasal göstergelerin yeterliliğinin yanında, bireyin temel yaşamsal ihtiyaçlarını gerçekleştirilebilmesi için yeterli zamanının olup olmadığı üzerine odaklanan Zacharias vd. (2014) ise, 2006 y1lı verileri altında Türkiye'deki tüketim harcamalarıyla zaman açı̆̆ı olarak adlandırdıkları yoksunluk göstergelerini (LIMTCP) ele almıştır. Çalışmaya göre bireyin (18-70 yaş) hanehalkı üretimine ve faaliyetlerine (ev işleri, çocuk bakımı vb.) ya da kişisel bakımına zaman ayıramaması, yoksulluğuna karşılık gelmektedir.

\section{Yoksunluk Endeksi ve Hesaplama Yöntemi}

Kaynaklara erişememe, toplumsal gerekliliklerin yerine getirilememesi ya da olması gereken optimum durumun elde edilememesi şeklinde ortaya çıkan yoksunluğun tespiti ve hangi durumun optimum koşul olduğunun belirlenmesi, birçok boyut ve göstergenin var olduğu bir koşulda oldukça karmaşık bir durumdur (Watson vd., 2008). Bu karmaşıklığı en aza indirebilmek için bu çalışmada kullanılan göstergelere ait soru ve yanıtlar ayrıntılı olarak incelenmiş ve genel kabul gören bir hayatın gerektirdiği asgari ihtiyaçların elde edilemediğini yansıtan yanıtlar yoksunluk göstergesi olarak kabul edilmiştir. İnsani gelişmeyi de yansıtan bu endeks ile kişilerin yoksunluklarının şiddeti ölçülürken; endeks değeri düşük olan bireylerin yüksek olanlara göre daha iyi 
yaşam koşullarına sahip oldukları söylenebilir (McLennan vd., 2011; Demir Şeker, 2011; Macculi, 2009).

Endeksin hesaplanmasındaki ilk aşamayı gerekli boyut ve göstergelerin belirlenmesi oluşturmaktadır ki bu çalışmada 8 boyut ve 58 gösterge ele alınmıştır (EK2). Bireyin bir göstergede yoksun olup olmadığını tespit etmek için ise öncelikle her göstergenin kendi yoksunluk sınırı oluşturulmuş (EK3), sonrasında bireyin sahip olduğu değer, bu yoksunluk sınırı ile karşılaştırılıp kişinin söz konusu göstergede yoksun olup olmadığı belirlenmiştir. $\mathrm{y}=\left[\mathrm{y}_{\mathrm{ij}}\right](\mathrm{n} \mathrm{x}$ d) matrisini gösterirken $y_{i j} \geq 0$ 'dır ve $i=1,2,3 \ldots, n$ kişiyi, $j=1,2,3, \ldots, d$ boyuttaki göstergeleri temsil etmektedir (Alkire ve Foster, 2007; 2011a; 2011b).

$$
\begin{aligned}
& Y=\left[\begin{array}{ccccc}
y_{11} & y_{12} & y_{13} & \cdot & y_{1 d} \\
y_{21} & y_{22} & y_{23} & \cdot & y_{2 d} \\
y_{31} & y_{32} & y_{33} & \cdot & y_{3 d} \\
\cdot & \cdot & \cdot & \cdot & \cdot \\
y_{n 1} & y_{n 2} & y_{n 3} & \cdot & y_{n d}
\end{array}\right] \quad \text { Kişi } \\
& Z=\left[\begin{array}{lllll}
z_{11} & z_{12} & z_{13} & \cdot & z_{1 d}
\end{array}\right] \quad \text { Yoksunluk sinır }
\end{aligned}
$$

(1) numaralı Y matrisinin var olduğu durumda; $y_{i j}$ i bireyinin $j$ boyutunda (göstergesinde) sahip olduğu değeri, (2) numaralı $\mathrm{z}_{1 \mathrm{j}}$ vektörü ise $\mathrm{y}_{\mathrm{ij}}$ vektörünü temsil eden, i. bireyin, j boyutundaki (göstergesindeki) değeri ile karşılaştırılacak olan sınırı, yani "yoksunluk sinırı"'nı temsil etmektedir". Bireyin değerinin sınırın altında/üstünde olması bu bireyin söz konusu göstergede, dolayısıyla da boyutta yoksun kabul edilmesini sağlamaktadır. Bir başka ifadeyle $\rho: \mathrm{R}_{+}{ }^{\mathrm{d}} \mathrm{x}$ $\mathrm{R}_{++}{ }^{\mathrm{d}} \rightarrow\{0,1\}$ iken; i. bireyin sahip olduğu değer vektörü ( $\mathrm{y} \in \mathrm{R}_{+}{ }^{\mathrm{d}}$ ) ile sınır vektörü $\left(z \in R_{++}{ }^{d}\right)$ karşılaştırılır. Eğer i. birey bir göstergede yoksun ise; $\rho\left(y_{i} ; z\right)=1$, yoksun değilse $\rho\left(y_{i} ; z\right)=0$ değerini alır. Bu matrisler yoksun bireylerin tespitinde önem arz ederken, bir sonraki aşamada uygulanacak olan "kısmi" ve "toplam yoksunluk endeksi”" hesaplamalarında gereklidir. Bir başka ifadeyle, söz konusu

4 Yoksunluk sinırının temsil eden z matrisi EK 3 yardımıyla elde edilmektedir. Bu tabloda, göstergelere ilişkin "yoksunluk sınırları ya da şartları" altı çizili yazım şekliyle vurgulanmaktadır. Her bir göstergenin yoksunluk sınırı ve bunu belirleme yöntemi kendine özgü ve farklı olmasından dolayı, bu konuda genelleme yapmak mümkün değildir. Örneğin gelir boyutu için; tasarruf göstergesinin yoksunluk sınırı "hayır" yanıtı iken, borç göstergesinin sınırı "evet" yanıtından oluşmaktadır. Buna karşın utanma hissetmeden yer alma boyutunda "ailesinden bir ferdinin fakir olmasından utanma" göstergesinde yoksunluk sinırı "katılıyorum" yanıtı iken; bu boyutun diğer göstergelerinde söz konusu sınır farklılaşmaktadır. 
matrisler, bireyin EK 3'te yer alan göstergelerde ve yoksunluk sinırları kabulü altında bireyin yoksunluk yaşayıp yaşamadığını anlamamıza yararken, bir sonraki başlık altında ele alınacak endeksler için hangi bireylerin yoksunluk yaşadığını $\left[\rho\left(\mathrm{y}_{\mathrm{i}} ; \mathrm{z}\right)=1\right]$; hangi bireylerin ise yoksunluk yaşamadığını $\left[\rho\left(\mathrm{y}_{\mathrm{i}} ; \mathrm{z}\right)=0\right]$ ifade etmektedir (Şekil 1'deki 1. adım).

\subsection{Kısmi (Boyutsal) Yoksunluk Endeksi}

Yoksunlukları belirlenen her bireyin toplam yoksunluk endeksinin hesaplanabilmesi için öncelikle bu bireylerin kısmi yani her bir boyuttaki yoksunluk endeksinin $\left(D_{i}^{m}\right)$ hesaplanmas1 gerekmektedir (Macculi, 2009). K1smi yoksunluk endeksi bireyin bir boyuttaki (örneğin iş, iş yeri güvenliği boyutu) yoksunluk endeksini ifade etmekte iken, endeks 0 ile 100 değerleri arasında yer almaktadır. Bir başka deyişle bu endeks, boyutsal yoksunluk endeksidir ve değer arttıkça kişinin bu boyuttaki yoksunluğunun da arttığı söylenebilir.

Kısmi yoksunluk endeksini yansıtan eşitlik 3 'te $D_{i}^{m}$ i bireyinin $\mathrm{m}$ boyutundaki yoksunluk endeksini, $w_{j}^{m} \mathrm{~m}$ boyutunun $\mathrm{j}$ göstergesinde yoksun olmayanların yüzdesini, $I_{j i}^{m}$ ise i bireyinin m boyutunun j göstergesinde yoksun olup olmadığını göstermektedir. Kişi söz konusu göstergede yoksunsa $I_{j i}^{m}=1$, değilse $I_{j i}^{m}=0$ değerini almaktadır (Şekil $1 ; \underline{1 . \text { adım }}$ ).

Yoksunluk endeksinin elde edilebilmesinde bir sonraki aşamada, gösterge başına yoksun olmayanların yüzdesi $\left(w_{j}^{m}\right)$ ile bireyin yoksunluk göstergesinin ( $\left.I_{j i}^{m}\right)$ çarpım işleminin yapılması ve bunun her bir boyut özelinde toplam sonucunun $\left(\sum_{j} w_{j}^{m} \times I_{j i}^{m}\right)$ elde edilmesi gerekmektedir (Şekil 1; 2. adım). Daha sonraki adımda bu toplam, söz konusu göstergede yoksun olmayanların yüzdesine bölünüp elde edilen değer de 100 ile çarpılır ve her bir bireyin, örneğin i bireyinin $m$ boyutundaki kısmi yoksunluk endeksi (eşitlik 3 ve 4) hesaplanmış olur (Şekil 1; 3. adım).

$D_{i}^{m}=\frac{\sum_{j} w_{j}^{m} \times I_{j i}^{m}}{\sum_{j} w_{j}^{m}} \times 100$ 
$D_{i}^{m}=\frac{\sum_{j}(j \text { göstergesinde yoksun olmayanların yüzdesi }) x\left(\begin{array}{c}\text { kiși yoksun ise }=1 \\ k \text { işi yoksun değilse }=0\end{array}\right)}{\sum_{j}(j \text { göstergesinde yoksun olmayanların yüzdesi })} \times 100$

\subsection{Toplam Yoksunluk Endeksi}

Toplam yoksunluk endeksi, bireylerin "kısmi yoksunluklarının ăgırlıkl toplamını" ifade etmekte ve bu değer de "0 ile 100 arasında" yer almaktadır (Macculi, 2009). Endeksin 0'dan uzaklaşması, bireyin yoksunluk şiddetinin artması anlamına gelmektedir. Toplam yoksunluk endeksinin 0 olması birey için ideal durumu ve bireyin hiçbir yoksunluğunun olmadığını temsil ederken, değerin 100 olması bireyin tüm boyut ve göstergelerde yoksunluk yaşadığı duruma karşıllık gelmektedir.

Kısmi yoksunluk endeksi belirlenen bireyin toplam yoksunluk endeksinin elde edilmesindeki aşamada ortalama ağırlık değerinin $\left(\bar{w}^{m}\right)$ de belirlenmesi gerekmektedir. Ağırlık değeri çalışmaya dahil edilen boyut sayısına bağlı olmakta ve çalışmada kaç boyut yer alıyorsa ona göre değişiklik göstermektedir. Bu çalışmada ağırlık değeri 8 boyutun yer almasından dolayı eşit ağırlık yöntemi

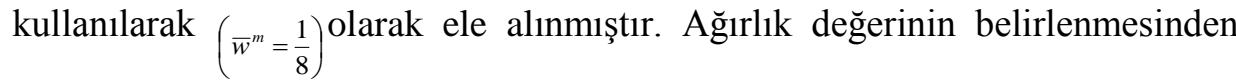
sonraki adımda ise hedeflenen toplam yoksunluk endeksi (eşitlik 5 ve 6) hesaplanabilir (Şekil 1, 4. adım).

$$
\begin{aligned}
D_{T i}=\frac{\sum_{m=1}^{M} \bar{w}^{m} \times D_{i}^{m}}{\sum_{m=1}^{M} \bar{w}^{m}} \\
D_{T i}=\frac{\sum_{m=1}^{M} \text { ortalama_agirlik) }_{(\text {her_boyutun_yoksunluk_endeksi) }}}{\sum_{m=1}^{M} \text { (ortalama_agirlik) }}
\end{aligned}
$$

Örneğin 1. sıradaki bireyin kısmi ve toplam yoksunluk endeksi, eşitlik 3 ve 5 kullanılarak aşağıdaki gibi hesaplanabilir;

Kismi yoksunluk endeksi:

$$
D_{1}^{m}=\frac{\sum_{j} w_{j}^{m} \times I_{j 1}^{m}}{\sum_{j} w_{j}^{m}} \times 100
$$


Toplam yoksunluk endeksi:

$$
D_{T 1}=\frac{\sum_{m=1}^{M} \bar{w}^{m} \times D_{1}^{m}}{\sum_{m=1}^{M} \bar{w}^{m}}=\frac{\frac{1}{8}\left(D_{g 1}^{g}+D_{e 1}^{e}+\ldots+D_{b 1}^{b}\right)}{8 \times\left(\frac{1}{8}\right)}=\frac{\frac{1}{8}\left(D_{g 1}^{g}+D_{e 1}^{e}+\ldots+D_{b 1}^{b}\right)}{1}
$$

Şekil 1: Yoksunluk Endeksinin Hesaplama Aşamaları

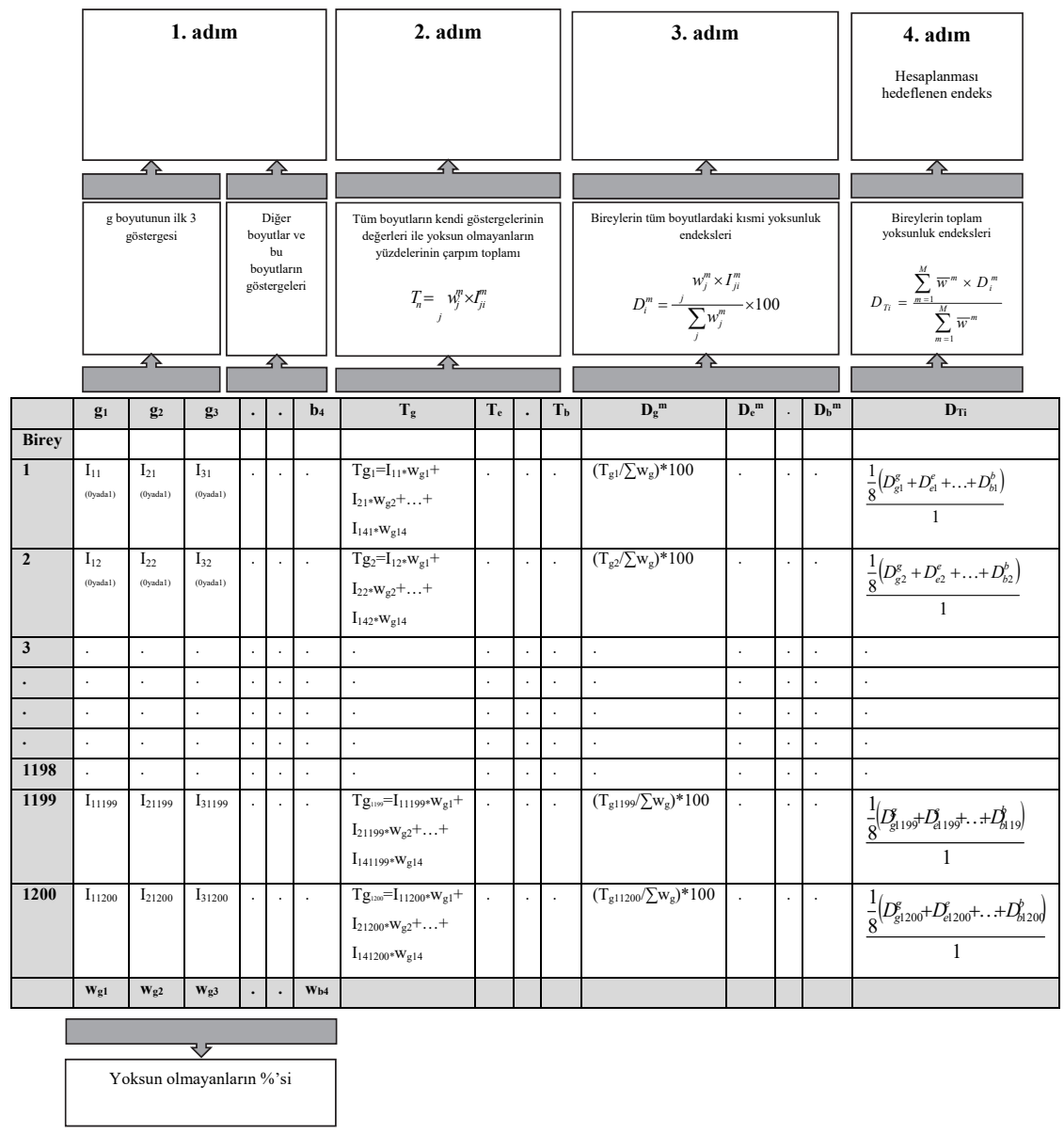

*1. adımda yer alan (0 / 1); "birey söz konusu göstergede yoksunsa 1, yoksun değilse 0” değerinin yazılacă̆ını ifade etmektedir. 


\section{Ampirik Analiz}

$\mathrm{Bu}$ başlık altında çalışmada kullanılan veri seti tanıtılacak, sonrasında ise Mersin ve Erzurum illerinde yaşayan bireylerin yoksunluklarını etkiyen faktörler tespit edilecektir.

\section{1. Örneklem}

Çalışmada gerçekleştirilen ampirik analiz için gereksinim duyulan veri, fert ve hanehalkı düzeyinde demografik ve sosyoekonomik istatistiki veriden oluşmaktadır. Bunun için 2011 yılında Mersin ve Erzurum illerinin kentsel alanlarında, her il için 600 hane ve 1200 ferdi kapsayan iki alan araştırmasında elde edilen veriler kullanılmıştır ${ }^{5,6,7}$. Analizin Mersin ve Erzurum illeri özelinde yapılmasının nedeni, Türkiye İstatistik Kurumu tarafından 2006 yılı sonrasında parasal yaklaşım ile yapılan yoksulluk hesaplamalarında, Mersin ve Erzurum'un sırasıyla iyileşme ve kötüleşme gösteren iki uçta yer alıyor olmalarıdır. Seçim nedeni olarak belirtilebilecek bir başka faktör de, dinamik bir yapıya sahip olan ve gelişme sürecine yön veren sosyoekonomik faktörlerin farklı yoğunluklardaki dağılımının, bölgelerarası gelişmişlik farklılıklarının temel nedeni olarak ortaya çıkması, Mersin ve Erzurum'un ise söz konusu farklılığı en iyi şekilde yansıtabilmesidir. Bu seçimi yaparken Kalkınma Bakanlığı'nın (önceki adıyla Devlet Planlama Teşkilatı-DPT) bu tür yansımaları ortaya koyabilmek ve faktörlerin farklı dağılımı sonucunda Türkiye'de ortaya çıkan sosyoekonomik gelişmişlik düzeylerini tespit edebilmek amacıyla, 1996 yılından bu yana yaklaşık her beş yılda bir hazırladığı ve illeri sıraladığı rapor temel alınmış, karşılaştırmayı mümkün kılabilmek ve aradaki gelişmişlik uçurumunu bertaraf edebilmek amacıyla en çok ve en az gelişmiş bölgelerdeki illerin seçilmemesine dikkat edilmiştir. Bu amaçla, analiz birimi olarak, endeks değeri 2. derece gelişmiş illerin ortalamasına en yakın olan Mersin ile 4. derece gelişmiş illerin ortalamasına en yakın olan Erzurum'un ele alınmasının altında; gelişmişlik düzeyleri farklı olan illerin yoksunluk şiddetlerinin hangi seviyede olduğu

5 Analizin 2011 tarihine ait verilerle yapılmasının temel gerekçesi, Türkiye ölçeğinde ya da il bazında sosyoekonomik göstergeleri içeren bu kapsamda bir veri setine ulaşılamamış olmasidir.

6 Örnekleme ilişkin tanımlayıcı istatistikler EK1'de sunulmuştur.

$7 \mathrm{Bu}$ çalışmada, Mersin ve Erzurum'un çok boyutlu yoksulluğunu ölçmek amaciyla örneklem seçiminin yapılması aşamasında, gelir elde eden hane ve bireylerin seçilmesine özen gösterilmiştir. Bu sayede, parasal olarak belirli bir düzeyde gelir elde eden bireylerin, sosyal göstergelerdeki durumunun ortaya çıkarılması hedeflenmiştir. Bu nedenle de hiçbir gelir elde edemeyen, bir başka deyişle, parasal göstergelerle yoksullun en yoksulu olan bireyler, örneklem seçimi aşamasında göz ardı edilmiş ve dışarıda tutulmuştur Zira belirtildiği üzere amaç parasal göstergelerin bireyin yaşam kalitesini yansıtmadaki eksikliğini ortaya koyabilmektir. 
merakı da yatmaktadır. Bu doğrultuda seçilen illerden Mersin, DPT'nin 1996 yılı çalışmasına göre ve 0,69 endeks değeri ile Türkiye'nin 10. en gelişmiş ili iken, Erzurum - 0,55 endeks değeri ile 56. gelişmiş ili olmuştur. Nüfusu daha fazla olan ve geleneksel bölge merkezlerine komşu ard bölgede yer alan Mersin'in şehirleşme oran1 \%62,14, Erzurum'un ise \%47,20'dir ki bu da Mersin'in kentleşme derecesinin daha yüksek olduğunun bir ifadesidir. Göstergeler arasındaki en önemli farklılıklardan birisi de göç oranında yaşanırken, analiz dönemi içerisinde göreli yoğun sanayi ve turizme dayalı gelişme gösteren Mersin'in \%64,94 oranla en fazla göç alan, Erzurum'un ise -\%103,61 oranla en fazla göç veren iller arasında yer aldığı da söylenebilir (DPT, 1996). Yıllar itibariyle Mersin'in gelişmişlik düzeyi hep Erzurum'un üzerinde yaşanmış, 2003 yılına gelindiğinde Türkiye'deki sıralamaları değişse de seviyeleri 1996 yılıyla paralellik göstermiş̧tir. DPT'nin 2003 yılı çalışmasına bakıldığında Mersin 0,51 endeks değeri ile Türkiye'nin en gelişmişs 17., Erzurum -0,53 değer ile 55. ili olduğu görülmektedir. Mersin 1996-2003 dönemi içerisinde gelişmişlik seviyesi en fazla gerileyen iller arasında yer alırken (6 sıra), aynı dönemde Erzurum'un gelişmişlik seviyesinde 1 sıra artış yaşanmıştır. Göstergeler tekil olarak incelendiğinde de, 2003 yılında, Mersin'in sahip olduğu değerlerin Erzurum'unkilere nazaran daha olumlu olduğu söylenebilir. Kalkınma Bakanlığı'nın anket uygulamasından sonra 2013 yılında yayınladığı, ancak anket yılıyla aynı dönemi (2011) kapsayan ve 61 göstergeli temel bileşenler analizinin yapıldığı bir diğer gelişmişlik sıralaması çalışması sonuçlarına göre de Mersin'in gelişmişlik sırası Erzurum'un üzerindedir. Mersin'in siralaması 2011 yılında 24.'lüğe gerilemiş olmasına karşın, Erzurum'un (59.) üzerindedir (Kalkınma Bakanlığ 1 , 2013).

Daha önce de belirtildiği gibi bu çalışmanın temel amacı, gelişmişlik düzeyleri farklı olan ve parasal göstergelerle yoksulluk seyri ayrı yönlerde hareket eden iki ilin, sosyal göstergelerin dahil edildiği bir yaklaşımla yoksunluk endeksini hesaplamak ve bu endeksi etkileyen faktörleri tespit etmektir ki örneklem olarak Mersin ve Erzurum'un ele alınmasının esas nedeni de budur. Çalışmada, örneklem genişliğinin belirlenmesi amacıyla "belirli özelliğe sahip birim oranı" için örneklem genişliği hesaplanmıştır. Belirlenen kitlelerle ilgili bu konuda daha önce bir çalışma yapılmamış olmasından dolayı, formüllerde kitle varyanslarının en büyük olduğu durum kullanılmış ve böylelikle örneklemlerin kitleleri en iyi şekilde temsil etmeleri sağlanmıştır. Örneklem genişliğinin elde edilebilmesi için ise eşitlik 9-10 kullanılmıştır (Yamane, 2010; Çıngı, 1994).

$$
n=\frac{n_{0}}{n_{0}+\frac{n_{0}-1}{N}}
$$


$n_{0}=\frac{z^{2} p q}{d^{2}}$

Burada n örneklem genişliği, z tablo değeri, d duyarlılık (hoşgörü) miktarı, $\mathrm{N}$ kitle büyüklüğ̈̈, pq çarpımı ise kitle varyansı olarak tanımlanmaktadır. $\mathrm{p}=\mathrm{q}=0,5$ için kitle varyansı en büyük değerini almakta ve eşitlik en büyük örneklem genişliği miktarını vermektedir. Buradan $\mathrm{z}=2 \mathrm{ve} \mathrm{d}=0,05$ için $\mathrm{N}$ sonsuza gittiği durumda minimum örneklem genişliği $n=400$ olarak elde edilebilir ${ }^{8,9}$.

Kayıp boyut sorununu göz önüne alarak hazırlanan bu çalışmanın yoksulluk anketi; istihdam, iş ve işyeri kalitesi; gelir; sağllk; güçlenme ${ }^{10}$; fiziksel güvenlik; utanma/dışlanmışlık hissetmeden yer alma; yaşamsal anlam ve değer; hanenin sosyoekonomik yapısı olmak üzere 8 ana bölümden ${ }^{11}$ ve 225 sorudan oluşmaktadır ${ }^{12,13}$. Parasal olmayan bir yoksulluğun hesaplanabilmesi için öncelikle kişilerin söz konusu boyutların hangilerinde yoksunluk yaşadığının tespit edilmesi gerekmektedir. Bu tespit aşamasında ise kişinin tüm boyutlardaki durumunu temsil eden göstergeye/göstergelere ve bunu karşılaştırmak amaciyla kullanılacak bir eşik değere/değerlere ${ }^{14}$ ihtiyaç varken, kişinin bir boyut ve göstergedeki yoksunluğunu belirleme yöntemi sorular için hazırlanmış cevaplara

8 İlgili istatistik yöntem örneklem sayısını 400 hane olarak belirlese de, elde edilen sonuçlar daha sonra çeşitli ekonometrik analizlerde de kullanılacağı için bu çalışma için ayrılan bütçe elverdiği ölçüde örneklem genişletilmeye çalış1lmış ve her il için 600 hane olarak belirlenmiştir.

9 Çalışmanın amaçları arasında cinsiyete bağlı bulguların da elde edilmesi olduğundan, her hanede eşlerle ayrı ayrı görüşülmüş, fert örneklemi her ilde $600 \times 2=1200$ kişiden oluşmuştur.

10 Literatürde kayıp boyutlar arasında yer alan "empowerment" boyutunun Türkçe karşıllı̆̆ı olarak daha çok "güçlendirme" kelimesi kullanılmaktadır: Ancak söz konusu karşılığın, boyutun ulaşmaya çalıştığı amacı tam olarak yansıtamaması ve "güçlendirme" kelimesinin "edilgen" bir yapıda olması nedeniyle bu çalışmada empowerment boyutunu "güçlenme" kelimesi temsil etmektedir. Böylelikle hanehalkı kararlarına katılmayı ve özerkliği yansıtan bu boyutun kelime anlamının da etken bir yapıyı ifade etmesi amaçlanmıştır. Bir başka anlatımla çalışmada, dişarıdan bir müdahale ya da etki olduğunu yansıtan "güçlendirme" kelimesi yerine, bireyin kendi iradesini yansıtan "güçlenme" kelimesi kullanılmıştır.

11 Çalışmada bu bölümler boyut olarak adlandırılmaktadır.

12 Çalışmada ele alınan göstergelerin ve değişkenlerin tespitinde yararlanılan bazı kaynaklar: Sen (1976; 1983; 1997; 1999; 2004) ve Foster vd.(1984), Bourguignon ve Chakravarty (2003), Alkire ve Foster (2007, 2011a, 2011b), Santos ve Ura (2008), Alkire ve Seth (2008), Battiston vd. (2009), Lugo ve Maasoumi (2008), Hammill (2009), Alkire ve Santos (2010), Bennett ve Mitra (2013), Batana (2013), Roche (2013), Akder (2000), Gürsel vd. (2013), Zacharias vd. (2014).

13 Alan araştırmasının sağlıklı bir şekilde yürütülebilmesi için, alan araştırması uygulamasından önce Mersin ve Erzurum illerine ziyaretlerde bulunulmuş, anketörlere gerekli eğitimler verilmiş ve ekonomik duruma göre sınıflandırılan bölgelerde pilot bir uygulama yapılmıştır.

14 Yoksunluk sınırı olarak da adlandırılır. 
göre değişmektedir. Kimi göstergelerde evet/hayır seçeneklerinden soruya göre uygunsuz olanı yoksunluk sınırı iken, kimi göstergelerdeki likert yönteminde ise istenen bazı yanıt haricindekiler yoksunluğu ifade edebilmektedir. $\mathrm{Bu} 8$ ana boyut hesaplamaya 42 ana gösterge ile dahil edilmiş olup, bazı ana göstergeler ağırlıklandırma yapılarak alt göstergelere ayrılmıştır ${ }^{15}$.

Göstergenin modeli etkileme derecesini belirleyen ağırlıklandırma yapılırken öncelikle her bir boyutun önem sırası ele alınmalıdır. Şöyle ki, eğer bir boyutun diğer boyutlara göre daha önemli olduğu düşünülmekte ise, bir başka deyişle, sadece o boyuta yönelik politikaların oluşturulması amaçlanıyor ise, söz konusu boyutun ağırlığı diğer boyutlara göre daha fazla olmakta, bu boyutun değerlerinin analizi etkileme gücü göreli yüksek olmaktadır. Örneğin karşılıksız emek olarak görülen kadınların hane içindeki statüsünü ön plana çıkarmaya yönelik bir çalışma yapıldığında, güçlenme boyutunun ağırlığı diğer boyutlara göre daha yüksek alınarak bu boyutun gücü arttırılabilir. Alt göstergelerle birlikte 58 göstergenin dahil edildiği bu çalışmada gelirin ve tüketim harcamasının seviyesinden ziyade, yoksulluğa neden olan kayıp boyutlar olarak adlandırılan tüm boyut ve göstergelerin ön planda tutulması amaçlanmıştır, ki bu nedenle çalışmada eşit ağırlıklandırma yöntemi uygulanmış, bir boyutun diğer boyuta göre üstün olmadığı, yani daha önemli olmadığı varsayılmıştır ${ }^{16}$. Bunun temel nedeni ise, çalışmanın, boyutların subjektif öneminin ortaya koyulmasını değil, tüm boyutların dahil olduğu bir yaklaşımla, illerin toplam yoksunluğunun ortaya çıkarılmasını amaç edinmiş olmasıdır.

Yapılan alan araştırması için kentsel alanlar ekonomik düzeye göre beş bölgeye ayrılmış ve bu ayrım Türkiye Araştırmacılar Derneği tarafından

$15 \mathrm{Bu}$ çalışmanın da temelini oluşturan $A F$ Yaklaşımını ilk uygulayan araştırmacılar olan Alkire ve Foster, küresel çok boyutlu yoksulluğu analiz ettikleri çalışmalarında, boyut olarak eğitim, sağlık ve yaşam standartları şeklinde 3 boyutu ele almıştır (Alkire ve Foster, 2007, 2011b). Araştırmacılar çalışmalarına eğitim boyutunun içerisinde 5 yaş altı okullaşma ve okula devam etme; sağlık boyutunun içerisinde çocuk ölümleri ve beslenme; yaşam standartları boyutunun içerisinde ise elektrik, temiz su, tuvalet, evin zemini, yemek için yakıt ve evdeki varlıklar (radyo, televizyon, bisiklet, motorsiklet, buzdolabı) şeklinde 10 göstergeyi dahil etmiş ve bu göstergelerden 3'ünde yoksunluk yaşayanları yoksul olarak tanımlamıştır. Ancak bu boyut ve göstergeler tüm ülkeler için genelleştirilemeyeceği ve bazı göstergelerin sadece yereli ya da kırsalı ilgilendirdiği için genel kabul görememiş, AF yaklaşımındaki küresel çok boyutlu yoksulluk endeksi boyut ve göstergelerine eklemelerin yapılması zorunluluğu ortaya çıkmış ve bu çalışmada da boyut ve gösterge sayısı yerel koşulların önemli olduğu varsayımıyla Türkiye'nin özel şartları göz önüne alınarak- bilerek farklılaştırılmıştır.

16 Eşit ağırlıklandırma olması durumunda; tüm boyutların ağırlık değeri aynı olur. Boyutlar içindeki göstergelerin ağırlığı ise, gösterge sayısına göre farklılık göstermektedir. Örneğin 8 boyutlu bu çalışmada tüm boyutların ağırlık değeri $1 \mathrm{iken,} \mathrm{boyutların} \mathrm{barındırdığı} \mathrm{göstergelerin}$ ağırlık değeri (1/gösterge sayısı)'dır. Eşit ağırlıklandırma olmaması durumunda; w: ağırlık katsayısı; d: boyut; $\mathrm{w}_{\mathrm{j}}: \mathrm{j}$ boyutunun ağırlı̆̆ $\mathrm{iken;}{ }^{w=\frac{d}{2}} w_{2}=\ldots . .=w_{j}=\frac{d}{2(d-1)}$ 
uygulanan, illerin sosyoekonomik seviyesine göre bölgesel ayrım metodu kullanılarak yapılmıştır (TÜAD, 2012). Ekonomik durumuna göre A-B-C-D-E bölgelerine ayrılan Mersin ve Erzurum'da, her alt bölgeye aynı sayıda anket uygulanmış ve her bir ilde alt bölge başına 120 hane 240 fert, il başına ise 600 hane 1200 ferde ait anket sonucu elde edilmiştir. Analizin seçilmiş illerin kentsel alanlarında yapılmasının gerekçesi ise, Türkiye'de en yüksek \%20'lik gelir dilimi dışındakilerin gelir dağılımlarının sürekli bozuluyor olması, özellikle kentlerde her geçen gün daha yüksek reel gelir kaybının yaşanması, yoksulluğun göç, barınma, sağlık, istihdam imkânları gibi nedenlerle kentlerde yaşayanlar için büyük bir sorun olmaya devam etmesi ve bu ekonomik bozulmanın sosyal etkilerinin kentlerde ne tür sonuçlar yarattığının ortaya çıkarılmasının hedeflenmiş olmasıdır (Oğuş, 2005; Eren ve Bahar, 2004). Ayrıca kırsal kesimde yoksulluğun daha ziyade tarım sektörüyle ilintili olması ve seçilen illerin kırsal kesimlerinin çok boyutlu yoksulluğu ölçmek için gerekli olan zemini barındırmaması da çalışmadaki kentsel analizin bir gerekçesidir. Bu bir anlamda, kaynak kısıtı nedeniyle Mersin ve Erzurum kırsal bölgelerinde ele alınan boyutlar ile ilgili sağlıklı veriye ulaşılamayacağına karşılık gelmektedir.

Anketin uygulandığ fert ve hanelere rastgele seçim yöntemiyle ulaşılırken, söz konusu anket hane halkı reisi ${ }^{17}$ ve eşinin aynı anda bulunduğu evlerde yüz yüze yapılmıştır. Her hanede, biri kadın biri erkek olmak üzere iki anketör görevlendirilmiş ve anket objektif yanıtların alınabilmesi amacıyla hane halkı reisi ve eşine ayrı odalarda uygulanmıştır. Anketin bir hanede uygulanabilmesinin bir başka ön koşulu ise, hane halkı reisinin çalışıyor olmasıdır, ki bunun gerekçesi, sonuçların parasal göstergelerle elde edilmiş bulgularla karşılaştırılabilmesidir. Yani çalışmada sürekli gelir elde eden bireylerin parasal olmayan göstergelerle yoksunluğunun ortaya çıkarılması hedeflenmiştir. Rastgele seçilen hanede hanehalkı reisi çalışmıyor ise o hane terk edilmiş ve anket uygulanmamıştır. Bu hedef doğrultusunda yoksulun en yoksulunu tespit etmek için eşlerin ikisinin de çalışmıyor olması gerekliliği ise göz ardı edilmiş̧ir. Zira belirtildiği üzere bu çalışmanın amacı, belirli bir miktar geliri olanların yoksunluğunu ortaya çıarmaktır. Hanehalkı reisinin tespitinin ardından reise çalışan fert anketi, eşine ise eğer bir işte çalışıyorsa çalışan fert anketi, çalışmıyorsa çalışmayan fert anketi uygulanmıştır ${ }^{18}$. Bu iki anket arasındaki temel fark, çalışmayan fert anketinde istihdam, iş ve işyeri kalitesi ile gelir boyutlarının bulunmamasıdır. Sonraki aşamada hem hanehalkı reisine hem de eşine, hanehalkının tümü ile ilgili soruların bulunduğu hanehalkı anketi uygulanmıştır.

17 Hanenin beyanına göre kadın ya da erkek.

18 Mersin örnekleminin \%44,41'i, Erzurum örnekleminin ise \%48,91'i çalışmamakta ve bu grup hanehalkı reisi eşlerinden oluşmaktadır. 


\subsection{Mersin ve Erzurum'da Yaşanan Yoksunluğun Genel Görünümü}

Mersin ve Erzurum illerinin kentsel alanlarında her il için 1200, toplamda 2400 bireye uygulanan anketlerin verileri ile yapılan çok boyutlu bir yoksulluk analizinin sonucunda; Mersin'de en fazla yoksunluk yaşanan boyutun "gelir" olduğu görülmektedir ki buradan hareketle Mersin'de 526 bireyin ya borcunun bulunduğu ya da herhangi bir tasarrufa sahip olmadığı söylenebilmektedir. $\mathrm{Bu}$ durum, il örnekleminin 1200 kişiden oluştuğu düşünüldüğünde, Mersin'de yaşayanların yaklaşık yarısının gelir yoksunu olduğunun da bir göstergesidir ${ }^{19}$. Tablo 1'de de görüldüğü üzere bu ildeki bireylerin en fazla yoksunluk yaşadıkları ikinci boyut ise utanma/dışlanmışlık hissetmeden yer alma boyutudur. Mersin için elde edilen bir diğer çarpıcı sonuç, örneklemde yer alan 449 bireyin, içinde bulunduğu sosyoekonomik durumdan dolayı utanıyor ya da dışlandığını hissediyor olmasıdır. Fiziksel güvenlik boyutu ise Mersin'deki boyutsal yoksunluk sıralamasında üçüncü sırada yer almakta ve bu kentte 423 birey, kendisinin ya da ailesinin fiziksel güvenliğinin tehlikede olduğunu düşünmektedir. İçinde bulunduğu sosyoekonomik durum ile mutlu bir yaşantıya sahip olamadığını düşünen birey sayısı ise 357'dir. Boyutsal yoksunluk sıralamasındaki en çarpıcı sonuç, Mersin'de güçlenme boyutunda yoksunluk yaşayan birey sayısının Erzurum'un gerisinde kalması ve güçlenmenin boyutsal sıralamada 7. sırada yer almasıdır ki Mersin örneklemindeki 1200 bireyin sadece 104'ü güçlenme boyutunda yoksundur. Mersin'deki bireylerin \%8,6's1, kadınların ise \%10,2'si güçlenme boyutu yoksunudur, yani karar alma mekanizmalarına dahil değildir, bir başka deyişle özerkliği yoktur. Mersin örnekleminin en az yoksunluk yaşadığı boyut ise sağlik boyutu olup, 77 kişinin sağlik boyutunda yoksunluğu bulunmaktadır.

Yoksunluk sıralamasında Erzurum'a bakıldığında da ilk sırada yine gelir yoksunluğunun yer aldığı söylenebilir. Bu örneklemde yer alan 391 kişi gelir yoksunu iken, bunu 318 yoksun kişi ile güçlenme boyutu izlemektedir. Mersin ile karşılaşıldığında bu sonuç oldukça önemlidir, zira Mersin'deki güçlenme boyutu yoksunluğu 7. sırada yer almakta ancak Erzurum'da bu durum 2. sira ile başı çekmektedir. Daha açık ifadeyle Mersin'deki tüm bireylerin yaklaşık \%9'u, Erzurum'dakilerin yaklaşık \%27'si güçlenme boyutu yoksunudur. Erzurum kadınlarının güçlenme boyutundaki yoksunluk oranı ise \%28'dir. Erzurum'un da içinde yer aldığı bölgede var olan erkek egemen yapı, özellikle kadınların karar

19 Çalışmada gelir yoksunluğunun göstergesi olarak gelirin düzeyinden ziyade bireyin borcunun olması ya da tasarrufunun olmaması ele alındığından dolayı, bireyin gelir seviyesine göre yaşam beklentileri göz ardı edilmiştir. Bir başka ifadeyle ne kadar yüksek gelirli ve yüksek yaşam beklentisine sahip olursa olsun, bireyin borçlu ve negatif tasarruflu olması, çalışmada, gelir yoksunu olarak kabul edilmesine neden olmaktadır. 
mekanizmalarına katılımlarını azaltması yönünde bir beklentiye neden olurken, sonuçlar beklentiyle uyumlu şekilde elde edilmiş ve Erzurum'daki güçlenme boyutu yoksunluğu daha yüksek çıkmıştır. Bunun yanında Mersin'de, Erzurum' dakilere göre lise ve üstü eğitimli birey sayısının daha fazla olması, yani eğitim seviyesinin nispeten öne çıkması, bu kentteki bireylerin güçlenmelerine olumlu yansımıştır.

Tablo 1: Boyutlardaki Yoksun Kişilerin Sayısı ve Boyutların Yoksunluk Sıralaması

\begin{tabular}{lcccccccc}
\hline & $\begin{array}{c}\text { İstihdam, Ișs } \\
\text { ve İşyeri } \\
\text { Güvenliği }\end{array}$ & Gelir & Sağlık & Güçlenme & $\begin{array}{c}\text { Utanma/ } \\
\text { Dışlanmışlık } \\
\text { Hissetmeden } \\
\text { Yer Alma }\end{array}$ & $\begin{array}{c}\text { Yaşamsal } \\
\text { Anlam ve } \\
\text { Değer }\end{array}$ & $\begin{array}{c}\text { Fiziksel } \\
\text { Güvenlik }\end{array}$ & $\begin{array}{c}\text { Hanenin } \\
\text { Sosyo- } \\
\text { ekonomik } \\
\text { Yapısı }\end{array}$ \\
\hline $\begin{array}{l}\text { Yoksun kişi } \\
\text { sayısı }\end{array}$ & 126 & 526 & 77 & 104 & 449 & 357 & 423 & 154 \\
\hline $\begin{array}{l}\text { Yoksunluk } \\
\text { sıralaması }\end{array}$ & 6. & 1. & 8. & 7. & 2. & 4. & 3. & 5. \\
\hline & 158 & 391 & 92 & 357 & 318 & 226 & 285 & 79 \\
\hline $\begin{array}{l}\text { Yoksun kişi } \\
\text { sayısı }\end{array}$ & 6. & 1. & 8. & 2. & 3. & 5. & 4. & 7. \\
\hline $\begin{array}{l}\text { Yoksunluk } \\
\text { siralaması }\end{array}$ & & & & & ERZURUM & & & \\
\hline
\end{tabular}

Tablo 2, Mersin ve Erzurum'da yaşayanların cinsiyet, yaş ve sosyoekonomik sınıflara göre yoksun kişi sayıları ile en az 3 boyutta yoksun olan birey sayılarını yansitırken, analizler sonucunda her iki ildeki kadınların erkeklere göre daha fazla yoksunluk yaşadığ sonucu elde edilmiştir. Bireyin yoksul kabul edilebilmesi için en az 3 boyutta yoksun olması gerekliliği ön kabulü altında Mersinli kadınların yoksulluk oranı $\% 5,8$, erkeklerin oran $1 \% 1,8$; Erzurumlu kadınların yoksulluk oranı \%5,7, erkeklerin oranı \%0,9'dur. Bu sonuçlar da hem Mersin hem de Erzurum'da yoksulluğun kadınlaştığının açık bir göstergesidir. Yoksulluğun kadınlaşmasının nedenleri arasında ise kadınların çoğunluğunun ortaokul seviyesi altında eğitim almış olmaları, bu nedenle de çalışılan işin yüksek gelirli olamaması, cinsiyete göre gelir eşitsizliğinin ortaya çıkması, yine kadınların çoğunluğunun ücretsiz aile işçisi olarak hanede yer almaları ve bu nedenle de eşlerine bağımlı olmaları gösterilebilir. Bu bağımlılık da beraberinde aile içi şiddeti, yaşamdan memnuniyetsizliği ve dışlanmışlığ getirebilmekte ve kadınların yoksullaşmasına yol açmaktadır.

Yoksunluğa yaş grupları açısından bakıldığında ise, orta yaş grubunun başı çektiği söylenebilir. Bir başka ifadeyle her iki ilin de önemli çoğunluğunu genç ve orta yaşlıların oluşturduğu (yaklaşık \%90) ve bu bireylerin yaşadığ yoksunluğun, yaşlılara göre daha yüksek olduğu, çalışmadan elde edilen bir diğer önemli bulgudur. Yoksunluk değerlerine eğitim açısından bakıldığında ise, eğitim seviyesi arttıkça yoksulluk oranı düşer beklentisine paralel olarak, 
üniversite ve lisansüstü eğitim almış olanların yaşadığı yoksunluğun tüm gruplar içinde en düşük seviyede elde edildiği görülmektedir. Mersin'deki üniversite ve üstünde eğitim almış 339 kişiden sadece 10 'u çok boyutlu yaklaşıma göre yoksul iken, bu grubun yoksulluk oranı sınırının 3 olduğu kabulü altında \%1,1'dir. Erzurum örnekleminin yoksulluk analizi sonuçlarına bakıldığında da Mersin'e benzer sonuçların elde edildiği söylenebilir.

Tablo 2'de sosyoekonomik siniflarda yer alan birey sayıları ile yoksunluk yaşayan kişi sayıları da gösterilmektedir. Tabloda göze çarpan en belirgin sonuçlardan birisi çalışmayan, emekçi ve nitelikli emekçi sınıflarında yer alan kişi sayısının, göreli olarak yüksek olduğudur. Burada belirtilmesi gereken önemli bir husus, yoksunluk yaşayanların sayısı kadar, bu yoksun sayısının sınıf içindeki payına odaklanma gerekliliğidir. Bu noktada örneklemler, sınıfların belirginleştirilmesi amacıyla birleştirilirken, Mersin ve Erzurum'da en az 3 boyutta yoksunluk yaşayan kişi sayısının 195 olduğu ve bu sayının, toplam örneklemin \%8,13'üne karşllık geldiği söylenebilir. Boyutlardaki yoksunluk yaşayan bireyler incelendiğinde ise tüm boyutlarda en fazla yoksunluğu örneklem yoğunluğuna paralel olarak- çalışmayan, emekçi ve nitelikli emekçi sınıflarının yaşadığı görülmektedir. Çalışmayan sınıfının kendi örnekleminin büyük (1119 kişi), yoksulluk sınırının 3 olması durumunda kişi sayısı oranının küçük olmasından dolayı (19/1119), yoksulluk oranı nispeten düşük çıkmıştır. Bu nedenle niteliklilerin de dahil edildiği durumda, "emekçiler" en fazla yoksunluk yaşayan sınıf olarak kendini göstermektedir.

Tablo 2: Cinsiyet, Yaş ve Sosyoekonomik Sınıflara Göre Yoksun Kişi Sayıları

\begin{tabular}{|c|c|c|c|}
\hline & & Kişi sayısı & $\begin{array}{c}\text { En az } 3 \text { Boyutta } \\
\text { Yoksun Kişi Sayısı }\end{array}$ \\
\hline \multirow{2}{*}{ Mersin } & Kadın & 600 & 76 \\
\hline & Erkek & 600 & 26 \\
\hline \multirow{2}{*}{ Erzurum } & Kadın & 600 & 78 \\
\hline & Erkek & 600 & 14 \\
\hline \multirow{3}{*}{ Mersin } & $15-34$ & 541 & 47 \\
\hline & $35-54$ & 563 & 51 \\
\hline & $55+$ & 96 & 4 \\
\hline \multirow{3}{*}{ Erzurum } & 15-34 & 630 & 50 \\
\hline & $35-54$ & 444 & 39 \\
\hline & $55+$ & 126 & 4 \\
\hline
\end{tabular}




\begin{tabular}{|c|c|c|c|}
\hline \multirow{3}{*}{ Mersin } & İlköğretim ve altı & 408 & 60 \\
\hline & Lise & 393 & 32 \\
\hline & Üniversite ve üstü & 399 & 10 \\
\hline \multirow{3}{*}{ Erzurum } & İlköğretim ve altı & 596 & 51 \\
\hline & Lise & 287 & 24 \\
\hline & Üniversite ve üstü & 317 & 18 \\
\hline \multirow{6}{*}{$\begin{array}{l}\text { Mersin + } \\
\text { Erzurum }\end{array}$} & Kapitalist & 233 & 18 \\
\hline & Kentli Profesyonel & 99 & 7 \\
\hline & Küçük Burjuva & 98 & 27 \\
\hline & Nitelikli Emekçi & 370 & 29 \\
\hline & Emekçi & 481 & 95 \\
\hline & Çalışmayan & 1119 & 19 \\
\hline
\end{tabular}

\subsection{Mersin ve Erzurum'un Yoksunluk Endeksi}

$\mathrm{Bu}$ çalışmanın temel bulgularından birisi Mersin ve Erzurum'da, düşük sosyoekonomik seviyede yaşayanların, kadınların, orta yaştakilerin, ilköğretim ile altında eğitimli olanların ve küçük burjuvalar ile emekçilerin şiddetli yoksunluk yaşadıklarıdır ${ }^{20}$. Bu noktada her birey için ayrı ayrı hesaplanan toplam yoksunluk endeksi değerleri, hangi bireyin daha fazla yoksunluk yaşadığına dair fikir verirken, ele alınan örneklemin ortalama yoksunluk endeksi birimler aras karşılaştırmalara olanak sağlamaktadır. Bu yolla endeks değeri göreli büyük olan birey ya da örneklemin sosyoekonomik açıdan diğerlerine göre daha kötü durumda olduğu sonucu ortaya çıkarılabilmektedir. Bu çalışmada Mersin ve Erzurum örneklemlerinde yer alan bireylerin yaşadıkları yoksunlukları ve bunları etkileyen faktörleri ortaya koyabilmek amacıyla öncelikle ikinci başlık altında tanıtılan yöntemle kısmi yoksunluk endeksleri, sonrasında da bu değerleri kullanarak toplam yoksunluk endeksleri elde edilmiştir. Her birey için 0 ile 100 değerleri arasında farklılık gösteren yoksunluk endeksi sonuçlarına göre (Tablo 3), Mersin'dekiler için bulunan en düşük değer 2,43 iken, Erzurum'dakiler için 0 'dır. Mersin'deki bireylerin en yüksek endeks değeri 53,88, Erzurum'dakilerin ise 61,71'dir. Örneklemlerine göre ayr1 ayr1 endeks ortalamalarının elde edilmesinin ardından Mersin'de yaşanan yoksunluğun Erzurum'un üzerinde olduğ $u$ söylenebilir. Bir başka ifadeyle en düşük ve ortalama endeks bakımından göreli avantajlı durumda olan Erzurum'un, Mersin'le kıyaslandığında daha iyi durumda olduğu belirtilebilir.

$20 \mathrm{Bu}$ çalışmada birey sınıf pozisyonlarının belirlenmesi işlemi EK6'daki sınıflandırmaya göre yapılmıştır. 
Bireylerin endeks değerleri küçükten büyüğe sıralandığında Mersin'in medyan değeri 20,05; Erzurum'un 17,39'dur. Bu sonuç da ortanca değer bakımından Erzurum'un ideal değer olan 0'a daha yakın olduğunun bir ifadesidir. Örneklemlerin endeks serilerinin çarpıklık ve basıklıkları (Skewness ve Kurtosis) incelendiğinde ise, bu katsayılarının sıfırdan büyük olması nedeniyle, hem Mersin hem de Erzurum serilerinin sağa çarpık ve standart normal dağglımdan daha sivri olduğu belirtilebilir. Sonuçlara ilişkin Tablo 3'te yer alan grafiklerde de söz konusu sağa çarpıklık ve sivrilik görülebilmektedir.

Tablo 3: Mersin ve Erzurum Örneklemlerinin Toplam Yoksunluk Endekslerinin Tanımlayıcı İstatistikleri

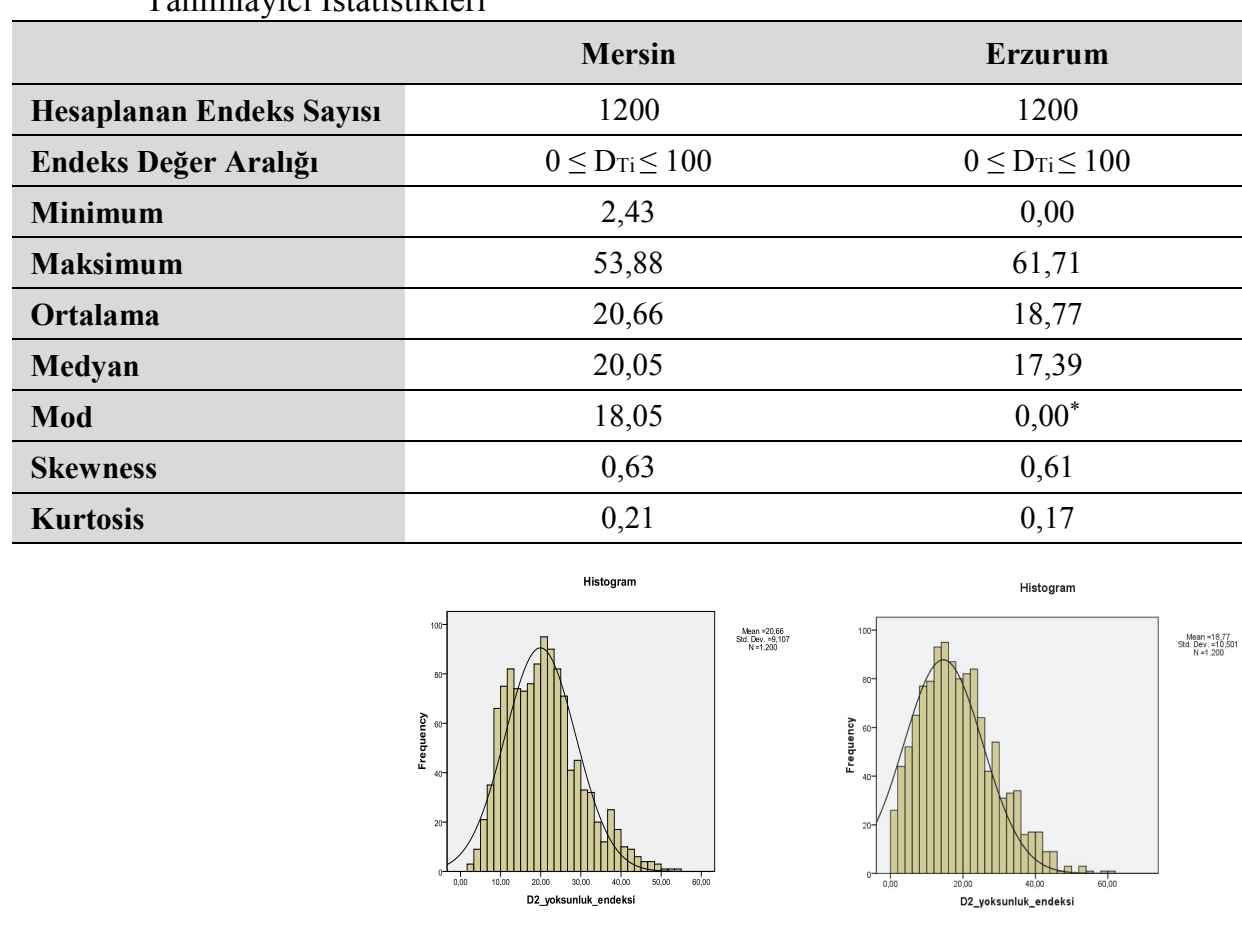

*: Tablodaki yer kısitı nedeniyle Erzurum mod değeri olarak sadece 0 de ğeri gösterilmiş, diğer mod değerlerine ise metin içinde değinilmiştir.

Endeks değerleri bireylere göre farklılaşan örneklemlerin endeks aralığg dağılımlarına bakıldığında (Tablo 4), hem Mersin hem de Erzurum'da en fazla yoksunluk yaşayan kişi sayısının 10-20 aralığında olduğu görülmektedir. Bir başka anlatımla Mersin'in yaklaşı \%39'u, Erzurum'un ise yaklaşık \%36'sı 10-20 arasındaki bir yoksunluk endeksine sahiptir. Endeks değerinin sıfıra yaklaşması bireyin daha az yoksunluk yaşadığı anlamına geldiğine göre, 0-10 arası endekse 
sahip olanların Erzurum'da daha fazla olması (\%22), bu ilde yaşanan yoksunluğun daha düşük olduğunun diğer bir kanıtıdır.

Tablo 4: Mersin ve Erzurum'daki Bireylerin Yoksunluk Endeksi Dağılımları

\begin{tabular}{lcccc}
\hline & \multicolumn{2}{c}{ Mersin } & \multicolumn{2}{c}{ Erzurum } \\
\hline Endeks Aralığı & Kişi & Kişi & \% \\
\hline $\mathbf{0 , 0 0 - 9 , 9 9}$ & 134 & 11,17 & 264 & 22,00 \\
\hline $\mathbf{1 0 , 0 0 - 1 9 , 9 9}$ & 464 & 38,67 & 434 & 36,17 \\
\hline $\mathbf{2 0 , 0 0 - 2 9 , 9 9}$ & 424 & 35,33 & 326 & 27,17 \\
\hline $\mathbf{3 0 , 0 0 - 3 9 , 9 9}$ & 139 & 11,58 & 131 & 10,92 \\
\hline $\mathbf{4 0 , 0 0 - 4 9 , 9 9}$ & 36 & 3,00 & 39 & 3,25 \\
\hline $\mathbf{5 0 , 0 0 +}$ & 3 & 0,25 & 6 & 0,50 \\
\hline $\mathbf{0 , 0 0 - 1 0 0 , 0 0}$ & $\mathbf{1 2 0 0}$ & $\mathbf{1 0 0 , 0 0}$ & $\mathbf{1 2 0 0}$ & $\mathbf{1 0 0 , 0 0}$ \\
\hline
\end{tabular}

\subsection{Yoksunluk Endeksini Etkileyen Faktörler}

Yoksunluk endeksleri hesaplanan bireylerin endekslerini etkileyen faktörlerin saptanmasının ve ardından belirlenen bu faktörlerin endeksi hangi yönde ve ne kadar etkilediğinin ön plana çıkarılmasının hedeflendiği bu bölüme, öncelikle endeksi etkilediği düşünülen ve ekonometrik analizde bağımsız değişken olarak belirlenen 67 değişken tanıtılmaktadır. Başlangıçta, uygulanan anketteki 225 soru içerisinden, bireylerin yoksunluklarını yansıtabilecek yanıtların yer aldığı 35 soru seçilmiş ve bunlar kukla değişkenler ile birlikte 72 bağımsız değişken olarak analize dahil edilmiştir. Seçilen değişkenler incelendiğinde, sürekli, likert ve sabit terim kukla olmak üzere 3 değişken tipi olduğu görülmektedir. Özellikle gelir ve gelire ilişkin bazı değişkenler açık uçlu soru şeklinde ankete dahil edildiğinden, bunların yanıtları sürekli değişken olarak analize katılmıştır. Kimi değişkenler ise yanıtların "1'den 5'e doğru olumlu yönde hareket ettiği" 5'li likert yöntemi ile modelde yer almıştır. Analize dahil edilen bir başka değişken türü sabit terim kukla değişkendir ve bunların baz değişkenlerine göre dönüşümleri yapılmıştır. Modelin tahmininden önceki son aşamada ise bağımsız değişken sayısı yapılan faktör analizi ile 67'ye düşürülmüştür (EK 5).

$\mathrm{Bu}$ çalışmada da uygulanan, birbiriyle ilişkili çok sayıdaki değişkeni, anlamlı ve birbirinden bağımsız hale getiren faktör analizinin temel amac1; değişken sayısını azaltmak, aynı özelliklere sahip değişkenleri sınıflandırmak ve değişkenler arasındaki ilişkilerden yararlanarak bazı yeni yapılar ortaya 
koymaktır ${ }^{21}$. Çalışmada Mersin ve Erzurum örneklemlerindeki aynı özellikli değişkenlerin sayısını azaltmak için faktör analizi 2 ana grup değişkeni üzerinde yapılmıştır. Güvenilirlik testlerinden geçen analizdeki istihdam, iş ve işyeri kalitesi ile güçlenme boyutlarındaki değişken grupları incelendiğinde; bireyin çalıştı̆̆ 1 ortamdaki özgürlüğünün, istihdam, iş ve işyeri boyutunda 5 değişken tarafindan temsil edilebildiği tespit edilmiştir (IIK_ASTUST_ILISKI, IIK_ISY_SAYGI, IIK_ISY_HAKSIZLIK, IIK_KARIYER_FIRS, IIK_ISY_OZGURLUK). Bu değişkenler için yapılan faktör analizi sonucunda 3'ünün modelden çlkarılabileceği ve IIK_KARIYER_FIRS, IIK_ISY_OZGURLUK değişkenlerinin bu grubu temsil edebileceği sonucuna varılmıştır. Güçlenme boyutundaki bireyin ve yakınlarının bugün ile 10 yıl önceki özgürlük durumlarını temsil eden değişkenler (GUC_OZGURLUK_DURUMU, GUC_YAKIN_OZGURLUK_DURUMU, GUC_1OYILONCE_OZGURLUK_DURUMU) ise faktör analizi sonucunda tek değişkene dönüştürülmüş ve modele sadece GUC_OZGURLUK_DURUMU değişkeni dahil edilmiştir.

Yoksunluk endeks değerleri hesaplanan bireylerin, bu değerlerinin hangi değişkenler tarafından, nasıl etkilendiklerinin analizinin yapıldığı bu başlık altında, Mersin ve Erzurum örneklemleri öncelikle cinsiyete göre ikiye ayrılmıştır. Bu işlemin yapılmasındaki amaç, kadın ve erkeklerin yoksunluklarını

21 Veri setinin faktör analizi için uygun olup olmadığını değerlendirmek amacıyla 3 yöntem kullanılmaktadır.

i) Analizde kullanılan tüm değişkenler için korelasyon matrisinin oluşturulması: Veri setinin faktör analizi için uygun olup olmadığının tespit edilmesinde ilk adım, değişkenler arasındaki korelasyon katsayılarının incelenmesidir. Değişkenler arasındaki korelasyonların yüksek olması istenilen durumu ifade etmektedir. Çünkü değişkenler arasındaki korelasyonlar ne kadar yüksek ise, değișkenlerin ortak faktörler oluşturma olasılıkları o kadar yüksektir. Başka bir ifade ile değişkenler arasında yüksek korelasyonların varlığı, değişkenlerin ortak faktörlerin değişik biçimlerdeki ölçümleri olduğunu gösterir. ii) Barlett testi (Barlett test of Sphericity): $\mathrm{Bu}$ test korelasyon matrisinde değişkenlerin en azından bir kısmı arasında yüksek oranlı korelasyonlar olduğu olasılığını test eder. Analize devam edilebilmesi için "Korelasyon matrisi birim matristir" sifir hipotezinin reddedilmesi gerekir. Eğer sıfir hipotezi reddedilirse, değişkenler arasında yüksek korelasyonlar olduğunu, başka bir deyişle veri setinin faktör analizi için uygun olduğunu gösterir. iii) Kaiser-Meyer-Olkin (KMO) örneklem yeterliliği ölçütü: Gözlenen korelasyon katsayıları büyüklüğü ile kısmi korelasyon katsayılarının büyüklügünü karşılaştıran bir indekstir. Oranın 0,5'in üzerinde olması gerekir ve oran ne kadar yüksek olursa veri seti faktör analizi yapmak için o kadar iyidir (Stapleton, 1997). Değişkenler arası korelasyonu ifade eden "gözlenen korelasyon katsayısı" yanında, değişkenlerden birinin etkisinin arındırılması durumunda "kısmi korelasyon katsayısı" da elde edilebilmektedir. Bu çalışmada faktör analizi yapılan istihdam, iş ve işyeri güvenliği boyutundaki değişken grubunun KMO testi; Mersin için 0,684, Erzurum için 0,764 iken; güçlenme boyutu için bu değerler sırasıyla 0,703 ve 0,725 'tir. Söz konusu değerlerin 0,5 'in üzerinde olması nedeniyle çalışmada faktör analizinin yapılması uygun görülmüştür. 
etkileyen unsurların farklılıklarını ön plana çıkarmak, cinsiyete ve illere göre bir karşılaştırma yapmaktır. Ayrımın yapılmasındaki bir başka neden de seçilen illerdeki çalışan kadın sayısının az olmasından dolayı, kadınların gelir ile istihdam iş ve işyeri güvenliği boyutlarına ilişkin verilerinin yeterli olmamasıdır. Ayrıca kadınların yoksunluklarının özellikle güçlenme boyutundaki değişkenler tarafından nasıl etkilendiğinin tespiti de cinsiyete göre analizin gerekçeleri arasında siralanabilir.

Hane ve hanehalkı sosyoekonomik durum, istihdam iş ve işyeri güvenliği, gelir, sağlık, güçlenme ve utanma/dışlanmışlık hissetmeden yer alma boyutlarındaki 67 gösterge (değişken) ile bireylerin yoksunluk endeksleri arasındaki ilişkinin analizinde ilk aşamada Mersin, sonrasında ise Erzurum ilinin cinsiyete göre ayrılmış örneklemleri üzerinde çalışılmıştır. Değiş̧kenler seçilirken yoksunluk endeksinin hesaplanmasında kullanılan göstergeler dışarıda bırakılmıştır. Yatay kesit verileri kullanarak en küçük kareler yöntemiyle 22 (EKKY) tahmin edilen sonuçlar, değişen varyans için White Testi ${ }^{23}$ ile sınanmış ve problem tespit edildiği durumlarda White'ın değişen varyans uyumlu tahmin edicileri kullanılmıştır.

$$
\text { YOKSUNLUK ENDEKSI }=f(H H S, I I K, G, S, G U C, U)
$$

\subsubsection{Mersin'deki Bireylerin Yoksunluk Endeksini Etkileyen Faktörler}

Yoksunluk endeksini etkileyen faktörlerin analizinde ilk aşamada Mersin ilinin cinsiyete göre ayrılmış örneklemi üzerinde çalışılmışırı. Tablo 5 'te ilk aşamada Mersin'de yaşayan kadınların yoksunluk endekslerini etkileyen faktörlerin tespiti için oluşturulan modelin tahmin sonuçları gösterilmektedir. Sonuçlar incelendiğinde sabit terim ve 12 değişkenin istatistiki olarak anlamlı çıktığı görülmektedir. Modelin düzeltilmiş $\mathrm{R}^{2}$ değeri \%37 iken, $\mathrm{F}$ istatistik değeri 36,37'dir. Farklı düzeylerde istatistiksel olarak anlamlı çıkan 12 değişkenden 2 'si sürekli, 1'i likert ve 9'u ise kukla değişkendir. Bu değişkenlerden sürekli olanı yoksunluk endeksi, kukla olanı ise otonom yoksunluk endeksi üzerindeki etkiyi

22 Çalışmada EKKY'nin tercih edilmesinin nedeni, bu modelin, katsayıların hesaplanmasına imkân vermesi ve elde edilen katsayıların güvenilirliğinin sınanmasının mümkün olmasıdır. Ayrıca bağımlı değişkenin (yoksunluk endeksinin) kukla değişken olmaması, yani sürekli değişken olması, EKKY'nin tercih edilmesindeki bir başka gerekçedir.

$23 \mathrm{Bu}$ teste göre, $\mathrm{m}$ denklemdeki bağımsız değişken sayısını, n örneklem büyüklüğünü temsil ediyor iken; $b$ terimi, oluşturulan yan regresyonda hata terimlerinin karesi alınarak elde edilen bağımlı değişken katsayısını ifade etmektedir.

$\mathrm{H}_{0}: \mathrm{b}_{2}=\mathrm{b}_{3}=\ldots . .=0 \quad \mathrm{H}_{1}: \mathrm{b}_{2} \neq \mathrm{b}_{3} \neq \ldots \ldots \neq 0 \quad \mathrm{n} \cdot \mathrm{R}^{2}<\chi^{2} \mathrm{~m}$ ise değişen varyans yoktur. $\mathrm{n} \cdot \mathrm{R}^{2}>\chi^{2} \mathrm{~m}$ ise değişen varyans vardır (Hill vd., 2011). 
yansıtmakta iken, likert ölçekli değişkenler ölçekteki bir birimlik değişmenin yoksunluk endeksini kaç birim etkilediğini ortaya koymaktadir ${ }^{24}$.

Sonuçlar incelendiğinde, Mersin'de yaşayan kadınların okula gitmemiş olmalarının otonom yoksunluk endeksi üzerindeki etkisinin, lise mezunlarına göre 3,88 birim daha fazla olduğu ve ferdin okula gitmemiş olmasının beklendiği gibi yoksunluğu arttırdığ 1 görülmektedir. (HHS_EGITIM_OKULA_GITMEDI). Buna karşın kadınların üniversite eğitimi almış olmaları ise otonom yoksunluk endeksini lise mezunlarına göre 2,77 birim daha az etkilemektedir ve yoksunluk üzerinde azaltıcı etki ortaya çıkarmaktadır (HHS_EGITIM_UNIVERSITE). Kadınların işteki statülerine bakıldığında işçi, yevmiyeli ve kendi hesabına düzensiz pozisyonundaki işlerde çalışmalarının, otonom yoksunluk endeksi üzerindeki etkisi, çalışmayan ${ }^{25}$ kadınlara göre sırasıyla 7,52, 13,97 ve 8,25 birim daha fazla olduğu ortaya çıkmaktadır. Bu kadınların yevmiyeli ya da düzensiz işlerde çalışıyor olması endeksi arttırması bakımından beklentiyle uyumlu iken (IIK_ISSTATU_YEVM, IIK_KENHES_DSIZ), ücretli olarak işçi statüsünde çalışıor olmasının endeksi arttırması (IIK_ISSTATU_UCRETLIISCI) beklentinin tersi yönündedir. Çünkü sayıları az da olsa düzenli olarak gelir elde edebilen kadınların işçi statüsünde çalışıyor olmasının yoksunluk endeksini azaltması beklenmektedir. Buna karşın özellikle düzensiz işlerde çalışma durumu, gelir akışının sekteye uğraması nedeniyle, bireyleri bir nevi zorunlu olarak yoksunluk yaşamaya doğru yönlendirmektedir. Ayrıca çoğunlukla iş bulabildikçe yevmiyeli çalışan kadınların gelirlerinin sürekli olmaması da yoksunluk şiddetinin artışıyla sonuçlanmaktadır.

Hanedeki tüm bireylerin gelirlerinden oluşan hanenin toplam gelir miktarı değişkeninin ve hanenin elde ediyorsa sosyal yardım miktarı değişkenlerinin yoksunluk endeksi üzerindeki azaltıcı etkisi çok düşük olmakla birlikte, işareti beklenenle uyumludur. (G_HANE_GELIR_MIKTARI, G_SOSYAL_YARDIM _MIKTARI). Düzenli olarak spor yapan Mersin'de yaşayan kadınları otonom yoksunluk endeksi üzerindeki etkisi ise spor yapmayanlara göre 1,92 birim az iken, spor otonom yoksunluk endeksi üzerinde azaltıcı yönde bir etki yaratmaktadır (S_DUZENLI_SPOR). Kadınların yaşamlarındaki değişikliklerin kendilerinden ziyade toplum tarafindan sağlanıyor olması, otonom yoksunluk endeksini 2,67 birim daha fazla etkilemekte ve dışa bağımlı bir yapı beklenenle

24 Bağımlı değişkenlere ait tanımlayıcı istatistikler EK7'de sunulmuştur.

$25 \mathrm{Bu}$ çalışmadaki anket her hanede, hanehalkı reisinin çalışıyor olması ön şartıyla 2 bireye (kadın ve erkek) uygulanmıştır. Örneklemdeki çalışmayan bireyler hanehalkı reisinin eşlerinden oluşmakta, ancak veri kısıtı nedeniyle işsizler ile istihdama dahil olmayan 15 ve daha yukarı yaştaki nüfusun oluşturduğu "işgücüne dahil olmayan nüfus" tam olarak ayırt edilememektedir. $\mathrm{Bu}$ nedenle, istihdam edilmeyen tüm fertlerin -aynı şeyi temsil etmemekle birlikte- söylem birlikteliğinin sağlanması amacıyla "çalışmayan" sınıfında toplulaştırılması uygun görülmüştür. Genel sınıflandırmaya ilişkin izlenen yöntem EK 6'da sunulmuşstur. 
uyumlu bir şekilde endeksi arttırmaktadır (GUC_DEG_SAG_TOPL). Kadının özgürlük seviyesini temsil eden GUC_OZGURLUK_DURUMU değişkeninde likert ölçekteki her bir birim artış, yoksunluk endeksini 1,36 birim azaltmaktadır. Bunun anlamı, birey ne kadar fazla özgürse o kadar az yoksundur. Örneklemdeki kadınlara karşı önyargılı davranışlar ise otonom yoksunluk endeksini, buna maruz kalmayanlara göre, 4,68 birim daha fazla etkilerken beklentiyle uyumlu olarak endeksi arttırıcı yönde etki yaratmaktadır (U_ONYARGILI_DAVRANIS). $\mathrm{Bu}$ önyargının nedeninin cinsiyet olması, kadınların otonom yoksunluk endeksini iş durumu olmasına göre 4,95 birim daha fazla etkilemekte ve endeksi arttırmaktadir (U_ONYARGI_NED_CINSIYET).

Tablo 5 aynı zamanda Mersin'de yaşayan erkeklerin yoksunluk endekslerini etkileyen faktörlerin tespiti için oluşturulan modelin tahmin sonuçlarını da göstermekte iken, sonuçlara bakıldığında 16 değişkenin istatistiki olarak anlamlı çıktığı görülmektedir. Modelin düzeltilmiş $\mathrm{R}^{2}$ değeri $\% 35, \mathrm{~F}$ istatistik değeri ise 36,67 elde edilmiş, tahminde anlamlı çıkan 16 değişkenin çoğunluğunu kukla değişkenler oluşturmuş ve bunlara ilaveten 3 değişkenin likert, 1 değişkenin ise sürekli olduğu sonucuna ulaşılmıştır. Mersin erkek regresyonuna dahil edilen eğitim seviyesi değişkenlerinden anlamlı çıkan (HHS_EGITIM_OKULA_GITMEDI) ve (HHS_EGITIM_ILKOKUL) değişkenlerinin otonom yoksunluk endeksini lise mezunlarına göre sırasıyla 12,31 ve 2,53 birim daha fazla arttırdığı görülmektedir. Bu durum eğitim seviyesi ile yoksunluk endeksi arasında ters yönlü ilişkinin olduğunun bir kanıtıdır. Çalışan erkeğin işveren ya da memur statüsünde çalışması ise otonom yoksunluk endeksini çalışmayanlara göre sırasıyla 2,08 ve 2,21 birim azaltırken, bu göstergeleri temsil eden değişkenlerin işaretleri beklendiği gibi negatif elde edilmiştir (IIK_ISSTATU_ISVEREN, IIK_ISSTATU_MAASLIMEMUR). Bu sonuç, kendi işyerinde, yanında en az bir kişi çalıştıran işveren ile devlete bağlı kurum ve kuruluşlarda devlet memuru olmanın, bu kişilerin yoksunluklarını azaltmada katkı sağladığı anlamına gelmektedir. Yine çalışan erkeklerin, çalıştıkları işyeri ile aralarında resmi bir iş sözleşmesinin olması da otonom yoksunluk endeksini azaltırken, bu değişkene ait katsayı -1,91'dir (IIK_SOZLESME). İşyerinde kariyer firsatını ve ifade özgürlüğünü temsil eden değişkenlerin likert ölçeğindeki her bir birim artış ise yoksunluk endeksini sırasıyla 1,84 ve 2,10 birim azaltmakta, bu değişkenlere ait işaret ise beklendiği gibi negatif olmaktadır (IIK_ISY_KARIYER_FIRS, IIK_ISY_IFADE_ $O Z G U R L U G U)$. Çünkü bir işyerinde kariyer firsatları ve özgürlükler arttıkça, çalışan birey daha mutlu olmakta ve eğer varsa yoksunluğunun şiddeti azalmaktadır. Hanede elde edilen toplam gelir miktarı da Mersin'de yaşayan erkeklerin yoksunluk endeksini -beklenenden az da olsa- azaltırken, değişkenin işareti tahmin edildiği gibi negatiftir. (G_HANE_GELIR_MIKTARI). Tıpk1 kadın örnekleminde olduğu şekilde, erkeklerin düzenli spor yapması da otonom 
yoksunluk endeksini spor yapmamasına göre 1,51 birim azaltmaktadır (S_DUZENLI_SPOR). Bireyin ailesinden ya da sosyal statüsünden memnun olmayıp, bunlara ilişkin değişiklikler istiyor olması da yoksunluğunu ve bu paralelde yoksunluk endeksini arttırmasi beklenmektedir (GUC_DEG ISTENEN_AILE, GUC_DEG_ISTENEN_STATU). Mersin'de yaşayan erkeklerin ailesine ve sosyal statüsüne iliş̧in değiştirmek istediği şeylerin olması, otonom yoksunluk endeksini çalıştı̆̆ işte değişiklik istemesine göre sırasıyla 11,85 ve 3,27 birim daha fazla etkilemekte iken, söz konusu değişkenlerin işareti de beklendiği gibi pozitif elde edilmiştir. Dışa bağımlılığı ve dolayısıyla özgür olamamayı temsil eden güçlenme boyutunda anlamlı çıkan diğer değişkenler ise, bireyin hayatındaki değişiklik kararlarının kimin tarafından verildiğini yansıtan GUC_DEG_SAG_AILE ve GUC_DEG_SAG_TOPL değişkenleridir. Bireyin bu kararları kendi başına alamaması güçlenme boyutundaki yoksunluğunu ifade ederken, ailesi tarafindan alınmas1 otonom yoksunluk endeksini 3,24 birim, toplum tarafindan alınması ise 3,90 birim daha fazla etkilemekte ve endeksi arttırmaktadır. Mersindeki erkeklerin kendisinin ve kendisi gibi insanların toplumda bir şeyleri değiştirebileceğine inanıyor olması, özgüveninin bir yansımasi iken, bu durum otonom yoksunluk endeksini 1,74 azaltmaktadır (GUC_TOPL_DEG_YAPABILME). Bireyin özgürlük derecesinin temsil edildiği (GUC_OZGURLUK_DURUMU) değişkeninin likert ölçeğindeki her bir birimlik artış da bireyin yoksunluk endeksini azaltmakta, bunun miktarı ise 1,82 birim olmaktadır. Mersin'deki erkeklere karşı önyargılı davranışların etnik nedenlerle yapılması ise otonom yoksunluk endeksini arttırmakta ve bu değişkene ait işaret beklendiği gibi pozitif olmaktadır (U_ONYARGI_NED_ETNIK).

Mersin kadın ve erkek örneklemlerinin analiz sonuçları incelendiğinde, kadınların toplam ve otonom yoksunluk endeksini 7 faktörün arttırdığı, 5 faktörün ise azalttığı söylenebilir. Erkeklerin toplam ve otonom endeksini ise 7 faktör arttırmakta iken 9 faktör azaltmaktadır. Kadınların endeks değerini en çok "arttıran" değiş̧kenler IIK_ISSTATU_YEVM, IIK_KENHES_DSIZ, HHS_EGITIM_OKULA_GITMEDI ve IIK_ISSTATU_UCRETLIISCI, erkeklerin HHS_EGITIM_OKULA_GITMEDI, U_ONYARGI_NED_ETNIK ve GUC_DEG_ISTENEN_AILE değişkenleridir. Söz konusu değeri kadınlarda en fazla "azaltan" değişken ise HHS_EGITIM_UNIVERSITE, erkeklerde IIK_ISSTATU_MAASLIMEMUR değişkenidir. Özellikle kadınların endeks değerini en fazla arttıran ve azaltan değişkenlerin "eğitim" grubunun içinde yer alması, kadınların eğitim düzeyinin önemi hakkında fikir verebilir. 
Tablo 5: Mersin Örnekleminin Tahmin Sonuçları

\begin{tabular}{|c|c|c|c|c|c|c|c|c|}
\hline \multicolumn{9}{|c|}{ Bağımlı Değişken: YOKSUNLUK_ENDEKSI } \\
\hline \multicolumn{9}{|l|}{ Yöntem: En Küçük Kareler } \\
\hline \multicolumn{9}{|c|}{ Örneklem: 600 Kadın, 600 Erkek, Gözlem sayısı: $600+600=1200$} \\
\hline \multicolumn{9}{|c|}{ White'in değişen varyansla tutarlı tahmin edicileri } \\
\hline & \multicolumn{3}{|c|}{ KADIN } & \multicolumn{3}{|c|}{ ERKEK } & \multirow[b]{2}{*}{$\begin{array}{c}\begin{array}{c}\text { Beklenen } \\
\text { işaret }\end{array} \\
\end{array}$} & \multirow[b]{2}{*}{$\begin{array}{c}\text { Değişken } \\
\text { türü }\end{array}$} \\
\hline Değişken & Katsayı & & Olasilık & Katsayı & & Olasilık & & \\
\hline C & $23,69^{*}$ & & 0,00 & $51,12 *$ & & 0,00 & & \\
\hline $\begin{array}{l}\text { HHS_EGITIM_OKULA_GITMED } \\
\text { I }\end{array}$ & $3,88 * * *$ & & 0,09 & $12,31 * *$ & & 0,02 & + & Kukla \\
\hline HHS_EGITIM_ILKOKUL & & & & $2,53 *$ & & 0,00 & + & Kukla \\
\hline HHS_EGITIM_UNIVERSITE & $-2,77^{*}$ & & 0,00 & & & & - & Kukla \\
\hline IIK_ISSTATU_ISVEREN & & & & $-2,08^{* *}$ & & 0,04 & - & Kukla \\
\hline IIK_ISSTATU_MAASLIMEMUR & & & & $-2,21 * *$ & & 0,02 & - & Kukla \\
\hline IIK_ISSTATU_UCRETLIISCI & $7,52^{*}$ & & 0,00 & & & & - & Kukla \\
\hline IIK_ISSTATU_YEVM & $13,97^{*}$ & & 0,00 & & & & + & Kukla \\
\hline IIK_KENHES_DSIZ & $8,25 * *$ & & 0,01 & & & & + & Kukla \\
\hline IIK_SOZLESME & & & & $-1,91^{* *}$ & & 0,02 & - & Kukla \\
\hline IIK_ISY_KARIYER_FIRS & & & & $-1,84 *$ & & 0,00 & - & Likert \\
\hline IIK_ISY_IFADE_OZGURLUGU & & & & $-2,10^{*}$ & & 0,00 & - & Likert \\
\hline G_HANE_GELIR_MIKTARI & $-0,0006^{*}$ & & 0,00 & $-0,0006^{* *}$ & & 0,01 & - & Sürekli \\
\hline G_SOSYAL_YARDIM_MIKTARI & $-0,20 *$ & & 0,00 & & & & - & Sürekli \\
\hline S_DUZENLI_SPOR & $-1,92 *$ & & 0,00 & $-1,51^{* *}$ & & 0,03 & - & Kukla \\
\hline GUC_DEG_ISTENEN_AILE & & & & $11,85^{* *}$ & & 0,02 & + & Kukla \\
\hline GUC_DEG_ISTENEN_STATU & & & & $3,27 * *$ & & 0,01 & + & Kukla \\
\hline GUC_DEG_SAG_AILE & & & & $3,24 *$ & & 0,00 & + & Kukla \\
\hline GUC_DEG_SAG_TOPL & $2,67 * * *$ & & 0,08 & $3,90^{* * *}$ & & 0,07 & + & Kukla \\
\hline GUC_TOPL_DEG_YAPABILME & & & & $-1,74 * *$ & & 0,04 & - & Kukla \\
\hline GUC_OZGURLUK_DURUMU & $-1,36^{*}$ & & 0,00 & $-1,82^{*}$ & & 0,00 & - & Likert \\
\hline U_ONYARGILI_DAVRANIS & $4,68^{*}$ & & 0,00 & & & & + & Kukla \\
\hline U_ONYARGI_NED_CINSIYET & $4,95^{*}$ & & 0,00 & & & & + & Kukla \\
\hline \multirow[t]{6}{*}{ U_ONYARGI_NED_ETNIK } & & & & $11,94 *$ & & 0,00 & + & Kukla \\
\hline & $\mathbf{R}^{2}$ & F-ist. & 36,37 & $\mathbf{R}^{2}$ & 0,37 & F-ist. 36,67 & & \\
\hline & Düz. $\mathbf{R}^{2}$ & \begin{tabular}{|rr}
0,37 & $\begin{array}{r}\text { Olasillk } \\
\text { (F-ist.) }\end{array}$ \\
\end{tabular} & 0,00 & Düz. $\mathbf{R}^{2}$ & 0,35 & $\begin{array}{rr}\begin{array}{r}\text { Olasilık } \\
\text { (F-ist.) }\end{array} & 0,00 \\
\end{array}$ & & \\
\hline & $\begin{array}{l}\text { Reg. std. } \\
\text { hatası } \\
\end{array}$ & 7,57 & & $\begin{array}{l}\text { Reg. std. } \\
\text { hatası }\end{array}$ & 7,47 & & & \\
\hline & Değişen va & & & Değiş̧en varyan & & & & \\
\hline & F-ist. & \begin{tabular}{rr|}
$\begin{array}{r}\text { Olasiluk } \\
\mathbf{F}(\mathbf{1 2 , 5 8 7})\end{array}$ \\
\end{tabular} & 0,01 & F-ist. & 1,66 & $\begin{array}{rr}\text { Olasiluk } & 0,01 \\
\mathbf{F}(\mathbf{1 6 , 5 8 3 )} & 0,51\end{array}$ & & \\
\hline
\end{tabular}

\footnotetext{
*.** ve *** strasıyla \%1, \%5 ve \%10 anlamlllık düzeyini ifade etmektedir.
} 
Mersin örneklemine en küçük kareler yöntemi yanında, aşamalı seçim yöntemi (stepwise) de uygulanmış ve hem kadınlar hem de erkeklerde, Tablo 5 'teki değişkenler haricinde, (G_EKODEME_MIKTARI) sürekli değişkeni de istatistiki olarak anlamlı çıkmıştır ancak bu değişkenin işareti beklenenin tersi yönde elde edilmiştir.

\subsubsection{Erzurum'daki Bireylerin Yoksunluk Endeksini Etkileyen Faktörler}

Yoksunluk endeksini etkileyen faktörlerin tespiti analizinde ikinci aşamada Erzurum ilinin cinsiyete göre ayrılmış örneklemi üzerinde çalışılmıştır. Sonuçları Tablo 6'da görülen Erzurum ilindeki kadınların yoksunluk endekslerini etkileyen faktörlerin tespiti için oluşturulan modelin tahmin sonuçlarına göre düzeltilmiş $\mathrm{R}^{2}$ değeri $\% 38, \mathrm{~F}$ istatistik değeri ise yaklaşık 37 olarak elde edilmiştir. İstatistiksel olarak anlamlı çıkan 10 bağımsız değişkenden 9'u kukla değişken iken 1'i likert ölçeklidir.

Tablo 6'ya göre hiç okula gitmeyen kadınların otonom yoksunluk endeksi üzerindeki etkisi lise mezunlarına göre 4,07 birim fazladır ve bu otonom yoksunluk endeksini arttırmaktadır (HHS_EGITIM_OKULA_GITMEDI). İş yerindeki statü olarak iş̧̧i pozisyonunda çalışan kadınların otonom yoksunluk üzerindeki etkisi ise baz değişken olan çalı̧̧mayanlara göre 13,37 birim fazla iken, bu değişkenin de işareti beklenenin tersi elde edilmiştir (IIK_ISSTATU_UCRETLIISCI). Kendi hesabına düzensiz olarak çalışan kadınların otonom yoksunluk endeksi üzerindeki etkisi ise yine çalışmayanlara göre 17,68 birim fazla olmuştur (IIK_KENHES_DSIZ). Bu sonuç örneklemde az sayıda da olsa çalışan kadınların işçi pozisyonunda ya da düzensiz işlerde yer almalarının otonom yoksunluk endeksi üzerindeki arttırıcı etkiyi yansıtması bakımından önemlidir26,27. Düzenli olarak spor yapanların otonom yoksunluk

26 Bu çalışmanın veri kaynağı olan ankette, işsizler ve işgücü piyasasına dahil olmayan nüfus tam olarak ayırt edilememektedir. Bu nedenle istihdam edilmeyen tüm nüfus, iş arayıp aramadığına bakılmaksızın "çalışmayan" grubunda toplulaştırılmıştır.

27 Mersin ve Erzurum örneklemi için yapılan sosyoekonomik sınıf yoksulluğu analizinde, en dezavantajlı sınıfın emekçi sınıfı olduğu sonucuna ulaşılmıştır. Aynı analizde kadınların da erkeklere göre daha yoksun ve çok boyutlu analize göre daha yoksul oldukları ortaya çıkmıştır. $\mathrm{Bu}$ nedenle özellikle işçi pozisyonunda ve düzensiz olarak, iş buldukça çalışan kadınların otonom yoksunluk endeksini arttırmaları beklenen yönde bir sonuçtur. Ayrıca bu noktada açıklığa kavuşturulması gereken bir diğer husus da, çalışan bireylerin yoksunluğunun, çalışmayanlara göre daha fazla olabileceğidir. Bireyin çalışmıyor olması, yoksulluğu üzerinde elbette ki etkilidir ancak burada bir çelişki gibi görülen durumun temel gerekçesi yoksunluk ve yoksulluk tanımından kaynaklanmaktadır. Yani bu çalışmanın da temel aldığı çok boyutlu yoksulluk yaklaşımına göre bireyin yoksul kabul edilebilmesi için gelir elbette gerekli ancak yeterli bir değişken değildir. Bir başka ifadeyle, bireyin yoksul sınıfında konumlandırılabilmesi 
endeksi üzerindeki etkisi ise spor yapmayanlara göre 1,04 birim azdır. Bir başka değişle spor yapmak otonom yoksunluk endeksi üzerinde azaltıcı yönde bir etki yaratmaktadır (S_DUZENLI_SPOR). Düzenli spor yapan bireylerin daha sağliklı olabilecekleri düşünüldüğünde, tahmin sonucunda bu değişkenin de işareti beklenenle uyumludur. Aynı şekilde bireylerin özgürlük durumlarını yansıtan güçlenme boyutuna ilişkin değişkenlere ait sonuçlar ve işaretler beklenen yönde elde edilmiştir. Erzurum'da yaşayan kadınların hayatında meydana gelen değişikliklerin kimin tarafından sağlandığı modelde 2 değişken ile temsil edilmekte iken, değişikliklerin aile ya da toplum tarafindan sağlanması, otonom yoksunluk endeksini, bireyin kendisi tarafından sağlanmasına göre daha fazla arttırmaktadır. Ayrıca kadının hayatına ilişkin değişikliklerin ailesi tarafından sağlanması, otonom yoksunluk endeksini kendisine tarafından sağlanmasına göre 4,09 birim, toplum tarafından sağlanması ise 6,66 birim fazla etkilediği sonucuna da ulaşılmıştır (GUC_DEG_SAG_AILE; GUC_DEG_SAG_TOPL). $\mathrm{Bu}$ da bireylerin kararlarındaki dışa bağımlılığının artmasının otonom yoksunluk endeksi üzerinde arttırıcı yönde bir etki yarattığının göstergesidir. Erzurum'da yaşayan kadınların kendisinin ya da kendisi gibi insanların toplumda bir şeylerin değiştirebileceğine inanıyor olması, otonom yoksunluk endekslerini inanmayanlara göre 1,33 birim daha az etkilemekte ve azaltmaktadır (GUC_TOPL_DEG_YAPABILME). Bireyin özgür olup olmadığını yansıtan GUC_OZGURLUK_DURUMU değişkeninde de likert ölçeğindeki her bir birim artış, yani bireyin özgürlüğündeki iyileşme, yoksunluk endeksi üzerinde 3,97

için, birden fazla boyutta (örneğin; gelir, güçlenme, sağlık, utanma hissetmeden yer alma boyutlarında-yoksulluk sınırına göre bu boyut sayısı değişebilir) yoksunluk yaşaması şarttır. Yani birey istihdam edilmediği durumda, hanehalkı kararlarına katılabiliyorsa yani güçlenmişse, utanma ve dişlanmadan yaşayabiliyorsa, sağlıklıysa, hanesinin sosyoekonomik yapısı iyiyse ve güvenli bir ortamda yaşıyorsa, bu yaklaşıma göre yoksul değildir. Ayrıca hanehalkı reisinin eşinin çalışmıyor olması durumunda, hane gelirinin yüksek olduğu varsayımıyla (reisin yüksek kazanç elde etmesi durumunda) birey parasal yaklaşıma göre de yoksul olmayabilir. Özetle bireyin çalışmaması yoksulluğunu garanti etmemektedir. Bu noktada; çalışmayanlara göre, düzensiz gelirliler ve yevmiyelilerin yoksunluk üzerindeki etkisinin daha çok olması, yukarıda yapılan tespitler ışı̆̆ında olağandır/olasıdır. Bir başka ifadeyle geliri ve yaşam koşulları çoğunlukla düzenli olmayan yevmiyeli emekçi bireyler, diğer boyutlarda da yoksunluk yaşıyorsa; eşi yüksek gelir elde eden bir "çalışmayan bireyden" daha yoksul olabilir. Buna temel gerekçe olarak ise, emekçi bireylerin işgücü piyasasının kırılgan yapısını göz önüne alarak ve işini kaybetmemek adına her türlü şartta çalışmaya razı olmaları gösterilebilir. İşveren baskısı, emekçilerin vasıflarına göre nispeten güvenli olmayan şartlarda çalıştırılmaları, sağlık imkânlarına erişimdeki yetersizlikler, düzensiz gelir elde edilmesinden kaynaklanan yaşamsal memnuniyetsizlikler, karar alma mekanizmalarına dahil olamama, düşük gelir elde edilmesinden dolayı fiziksel güvenliği tehdit eden bölgelerde yaşama zorunluluğu, aynı gerekçeyle kendisinin ve aile fertlerinin eğitim imkanlarına ulaşmasındaki aksaklıklar ve eğitimi yarıda bırakma, etnik kökenden dolayı dışlanma gibi hususlar, emekçilerin örneklem içerisinde en yoksul kesim olmasına yol açmıştır. Buradan hareketle, politika yapıcıların yoksulluğa odaklanırken başlangıçta emekçi sınıfını göz önüne almaları, sosyal politikalardan beklenen etkiyi arttırabilir. 
birim negatif etki yaratmakta, bir başka değişle endeksi azaltmaktadır. Nedeni ne olursa olsun bireye karşı önyargılı bir davranış da otonom yoksunluk endeksini arttırırken, ön yargının nedeninin etnik olması, iş durumu olmasına göre 4,43 birim, cinsiyete bağlı olması ise 4,28 birim daha fazla etki yaratmakta ve otonom endeksi arttırmaktadır (U_ONYARGI_NED_ETNIK; U_ONYARGI_NED_ CINSIYET).

Tablo 6 Erzurum'da yaşayan erkeklerin yoksunluk endekslerini etkileyen faktörlerin tespiti için oluşturulan modelin tahmin sonuçlarını da göstermektedir ve tahminler sonucunda bu grup için de 10 değişkenin istatistiksel olarak anlamlı çıktığı görülmektedir. Modelin $\mathrm{F}$ istatistik değeri 31,24, düzeltilmiş $\mathrm{R}^{2}$ değeri ise \%34 olarak elde edilmiştir. Tahmin sonucunda istatistiki olarak anlamlı çıan 10 değişkenden 2'si sürekli, 2'si likert ve 4'ü kukla değişkendir. $\mathrm{Bu}$ değişkenlerden hanedeki fert sayısını temsil eden (HHS_HH_SAYISI) değişkenindeki bir birimlik değişme yoksunluk endeksini 0,86 birim arttırmaktadır. Modelin tahmininden önce bu değişkene ilişkin işaret beklentisi (+-) olmuştur. Erzurum örneklemi incelendiğinde, hanelerde genellikle hanehalkı reisinin çalıştığı; eş, çocuk ve varsa çalışma yaşındaki yaşlıların çalışmadığ 1 görülmektedir. Bu nedenle Erzurum örnekleminde hanehalkı sayısındaki artış, beklendiği gibi erkeklerin yoksunluk endeksini arttırmaktadır. Erzurum'da yaşayan erkeklerin üniversite eğitimi almış olmalarının yoksunluk endeksi üzerindeki etkisi ise lise mezunlarına göre 2,53 birim daha azdır ve bireyin üniversite mezunu olması beklendiği üzere otonom yoksunluğu azaltmaktadır (HHS_EGITIM_UNIVERSITE). Daha az gelir elde etme pahasina daha az çalışmayı tercih etmeyi temsil eden IIK_AZ_GELIR_CALISMA değişkenin işareti de beklenen yönde çıkmıştır ve daha az gelir pahasına daha az çalışmak isteyenlerin otonom yoksunluk endeksi üzerindeki etkisi, istemeyenlere göre 3,35 birim daha fazla olmuştur. Erzurum'da yaşayan erkeklerin işyerinde işçi pozisyonunda çalışmasının otonom yoksunluk endeksi üzerindeki etkisi ise çalışmayanlara göre 1,51 birim daha fazladır (IIK_ISSTATU_UCRETLIISCI). Çalışan erkeklerin çalıştıkları işyerinde ifade özgürlüklerinin artması tahmin edildiği gibi yoksunluk endeksi üzerinde negatif etki yaratırken, ifade özgürlügünün likert ölçeğindeki 1 birim artış, endeksi 2,11 birim azaltmaktadır (IIK_ISY_IFADE_OZGURLUGU). Ücret değişkeninin (G_UCRET_MIKTARI) işareti de beklenenle uyumlu olmuş ve ücretlerdeki artışın yoksunluk endeksini azalttığı görülmüştür. Erzurum'daki bir erkeğin hayatında meydana gelen değişikliklerin ailesi tarafından sağlanması, otonom yoksunluk endeksini bireyin kendisine göre 3,40 birim daha fazla etkilemekte iken, buna ilişkin kararlarda dışa bağımlı olması endeksi artırmaktadır (GUC_DEG_SAG_AILE). Bireyin kendisinin ya da kendisi gibi insanların toplumda bir şeylerin değiştirebileceğine inanıyor olması, otonom yoksunluk endekslerini, hiçbir şeyi değiştiremeyeceğine inanlara göre, 1,73 birim daha az etkilemektedir ve 
beklendiği üzere endeksi azaltmaktadır (GUC_TOPL_DEG_YAPABILME). Ayrıca bireyin özgürlüğünü yansıtan (GUC_OZGURLUK_DURUMU) değişkenin likert ölçeğindeki her bir birim artış ise, yoksunluk endeksi üzerinde 3,48 birim azaltıcı etki yaratmaktadır. Erzurum'da yaşayan erkeklere karşı önyargılı bir davranışın sergilenmesi, otonom yoksunluk endeksini bu davranışla karşılaşmayanlara göre 7,57 birim daha fazla etkilerken, bu davranışlar beklentiyle uyumlu olarak, endeksi arttırıcı yönde etki yaratmaktadır.

Erzurum kadın ve erkek örneklemlerinin ekonometrik analiz sonuçları incelendiğinde, kadınların toplam ve otonom yoksunluk endeksini 7 faktörün arttırdığ 1,3 faktörün ise azalttığı sonucuna varılmıştır. Erkeklerin yoksunluk endeksi ve otonom yoksunluklarını ise 5 faktör arttırmakta ve yine aynı sayıda faktör azaltmaktadır. Endeks değerini kadınlarda en çok arttıran değişkenler IIK_ISSTATU_UCRETLIISCI ve IIK_KENHES_DSIZ, erkeklerde U_ONYARGILI_DAVRANIS olmuştur. Hem kadınlar hem de erkekler için söz konusu endeks değerlerini en fazla azaltan değişken ise GUC_OZGURLUK_DURUMU değişkenidir.

Tablo 6: Erzurum Örnekleminin Tahmin Sonuçları

\begin{tabular}{|c|c|c|c|c|c|c|}
\hline \multicolumn{7}{|c|}{ Bağımlı Değişken: YOKSUNLUK_ENDEKSI } \\
\hline \multicolumn{7}{|l|}{ Yöntem: En Küçük Kareler } \\
\hline \multicolumn{7}{|c|}{ Örneklem: 600 Kadın, 600 Erkek, Gözlem sayısı: $600+600=1200$} \\
\hline \multicolumn{7}{|c|}{ White'ın değişen varyansla tutarlı tahmin edicileri } \\
\hline & \multicolumn{2}{|c|}{ KADIN } & \multicolumn{2}{|c|}{ ERKEK } & & \\
\hline Değişken & Katsayı & Olasılık & Katsayı & Olasilık & $\begin{array}{l}\text { Beklenen } \\
\text { işaret }\end{array}$ & $\begin{array}{l}\text { Değişken } \\
\text { türü }\end{array}$ \\
\hline $\mathbf{C}$ & $26,98 *$ & 0,00 & $40,54 *$ & 0,00 & & \\
\hline HHS_HH_SAYISI & & & $0,86^{*}$ & 0,00 & +- & Sürekli \\
\hline HHS_EGITIM_OKULA_GITMEDI & $4,07^{*}$ & 0,00 & & & + & Kukla \\
\hline HHS_EGITIM_UNIVERSITE & & & $-2,53 *$ & 0,00 & - & Kukla \\
\hline IIK_AZ_GELIR_CALISMA & & & $3,35^{*}$ & 0,00 & + & Kukla \\
\hline IIK_ISSTATU_UCRETLIISCI & $13,37^{*}$ & 0,00 & $1,51 * * *$ & 0,06 & - & Kukla \\
\hline IIK_KENHES_DSIZ & $17,68^{*}$ & 0,00 & & & + & Kukla \\
\hline IIK_ISY_IFADE_OZGURLUGU & & & $-2,11 *$ & 0,00 & - & Likert \\
\hline G_UCRET_MIKTARI & & & $-0,0002^{* *}$ & 0,01 & - & Sürekli \\
\hline S_DUZENLI_SPOR & $-1,04 * * *$ & 0,09 & & & - & Kukla \\
\hline GUC_DEG_SAG_AILE & $4,09^{*}$ & 0,000 & $3,40^{* *}$ & 0,01 & + & Kukla \\
\hline GUC_DEG_SAG_TOPL & $6,66 * *$ & 0,01 & & & + & Kukla \\
\hline GUC_TOPL_DEG_YAPABILME & $-1,33^{* *}$ & 0,03 & $-1,73 * *$ & 0,01 & - & Kukla \\
\hline
\end{tabular}




\begin{tabular}{|c|c|c|c|c|c|c|c|c|c|}
\hline \multirow{2}{*}{$\frac{\text { GUC_OZGURLUK_DURUMU }}{\text { U_ONYARGILI_DAVRANIS }}$} & \multicolumn{2}{|l|}{$-3,97 *$} & \multicolumn{2}{|l|}{0,00} & \multicolumn{2}{|l|}{$-3,48^{*}$} & \multicolumn{2}{|c|}{0,00} & Likert \\
\hline & & & & & $7,57^{*}$ & & 0,0 & 0 & Kukla \\
\hline U_ONYARGI_NED_ETNIK & $4,43^{* * * *}$ & & 0,06 & & & & & & Kukla \\
\hline \multirow[t]{6}{*}{ U_ONYARGI_NED_CINSIYET } & $4,28 * *$ & & 0,01 & & & & & & Kukla \\
\hline & $\overline{R^{2}}$ & 0,38 & F-ist. & 36,37 & $\overline{\mathbf{R}^{2}}$ & 0,35 & F-ist. & 31,24 & \\
\hline & Düz. $\mathbf{R}^{2}$ & 0,37 & $\begin{array}{l}\text { Olasilhk } \\
\text { (F-ist.) }\end{array}$ & 0,00 & Düz. $\mathrm{R}^{2}$ & 0,34 & $\begin{array}{l}\text { Olasilkk } \\
\text { (F-ist.) }\end{array}$ & 0,00 & \\
\hline & $\begin{array}{l}\text { Reg. std. } \\
\text { hatası }\end{array}$ & 7,26 & & & $\begin{array}{l}\text { Reg. std. } \\
\text { hatası }\end{array}$ & 8,52 & & & \\
\hline & Değişen va & ryans & & & Değiş̧en v & ans & & & \\
\hline & F-ist. & 1,85 & $\begin{array}{l}\text { Olasiluk } \\
\text { F(10,589) }\end{array}$ & 0,00 & F-ist. & 1,85 & $\begin{array}{l}\text { Olasilık } \\
F(10,589)\end{array}$ & 0,00 & \\
\hline
\end{tabular}

*, **ve *** sirasıyla \%1, \%5 ve \%10 anlamlllı düzeyini ifade etmektedir.

Erzurum için en küçük kareler yönteminin ardından uygulanan aşamalı seçim yöntemi sonuçlarına göre hem kadınlar hem de erkeklerde G_OZTUKETIM_ORANI; S_SAGLIK_SORUNUNA_KARSI_DAVRANIS ve GUC_DEG_ISTENEN_STATU değişkenleri de istatistiki olarak anlamlı çıkmış ve bunlardan G_OZTUKETIM_ORANI; S_SAGLIK_SORUNUNA_KARSI_ $D A V R A N I S$ değiş̧kenlerinin işareti beklenin tersi yönünde, $G U C_{-} D E G_{-}$ ISTENEN_STATU değişkeninin işareti ise beklenenle aynı yönde elde edilmiştir.

Özetle, bireylerin yoksunluk endekslerini etkileyen faktörler incelendiğinde, kadınlar için yevmiyeli, kendi hesabına düzensiz işlerde ve işçi statüsünde çalışma ile okula gitmemiş olma faktörlerinin; erkekler için ise yine okula gitmemiş olma ile başta etnik nedenler olmak üzere kendisine önyargılı davranıldığına inanma faktörlerinin, yoksunluk endekslerini en fazla arttıran unsurlar oldukları söylenebilir. Bu endeksleri en fazla azaltan, yani bireyleri yoksulluklarından kurtulmalarına yardımcı olabilecek faktörler ise; kadınların üniversite eğitimi almış, erkeklerin memur statüsünde çalışıyor olmalarıdır. Ayrıca hem kadın hem de erkeklerin özgürlük durumları, yani kendi kararlarını kendilerinin verebiliyor olmaları da, söz konusu endeksleri azaltan faktörler arasında sıralanabilir. Bu sonuçlar, yoksulluğun sadece parasal bir sorun olmadığının ve yoksulluğun gelirden başka faktörler tarafından da etkilendiğinin bir başka kanıtıdır. Ayrıca sonuçların cinsiyete göre farklılaşması da, bu soruna karşı farklı politikalarla yaklaşılması gerektiği konusunda bir ipucu niteliği taşımaktadır.

\section{Sonuç}

$\mathrm{Bu}$ çalışma, gelir yanında diğer sosyoekonomik değişkenlerin de dahil edildiği bir çerçevede, Mersin ve Erzurum illerinde yaşayan bireylerin yoksunlukları üzerinde etkili olan faktörleri tespit etmek ve parasal yöntemlerin 
bireylerin yaşam kalitesini yansıtmalarındaki eksikliği ortaya koyarak, bir anlamda "görünmeyen yoksulluğu" açığa çıkarmayı amaç edinmiştir. Mersin ve Erzurum illerinde toplam 2400 kadın ve erkek ile yüz yüze yapılan anket sonuçları verilerinin kullanıldığı çalışmada yoksunluk sınırı her bir gösterge için ayrı ayrı belirlenmiştir. Bu veriler ışığında hesaplanan yoksunluk endeksi ortalamalarına göre Mersin'de yaşanan yoksunluğun, Erzurum'un üzerinde olduğu görülmektedir. Bu sonuç özellikle geliri temel alan parasal yöntemlerle yapılan çalışmaların sonuçlarının tersi yönündedir ki özellikle TÜiK ve Kalkınma Bakanlığı'nın yoksulluk ya da gelişmişlik analizlerinde Mersin'in nispeten daha iyi konumda olduğu vurgulanmaktadır. Ortaya çıkan bu farklılığın ardından, gelirin bireylerin refah seviyelerini yansıtmada gerekli, ancak yeterli olmadığı sonucuna ulaşılabilir. Ele alınan illerde yoksunluğun en yoğun hissedildiği boyutlar incelendiğinde, tasarruf ve borç sahipliğini temsil eden gelir boyutunun her iki ilde de öne çıtı̆̆ görülmektedir. Mersin ve Erzurum örneklemlerinin yaklaşı yarısı ya borçlu ya da herhangi bir tasarrufa sahip olmadan yaşamlarını sürdürmektedir, ki bu sonuç ele alınan illerde parasal yoksulluğun da yoğun olduğunun bir işaretidir. Analizde öne çıkan en belirgin farklılık ise güçlenme boyutunda yoksunluk yaşayan kişi sayısında görülmekte ve bu boyutta Mersin'de 104, Erzurum'da ise 357 kişinin yoksun olduğu sonucuna ulaşılmaktadır. Bu sonuca bakıldığında, Mersin'de yaşayanların karar alma mekanizmalarında daha az dışa (eşine ya da ailesinin diğer fertlerine) bağımlı oldukları söylenebilir. Bu farklılığın bir nedeni olarak, geleneksel yapının özellikle Erzurum kadınlarının önünde bir engel teşkil etmiş olması gösterilebilir.

Hem Mersin hem de Erzurum'da, en düşük sosyoekonomik seviyede yaşayanların, kadınların, orta yaştakilerin, ilköğretim ile altında eğitimli olanların ve küçük burjuvalar ile emekçilerin daha yüksek oranda yoksulluk yaşamakta oldukları, bu çalışmadan elde edilen önemli bulgular arasında sıralanabilir. Bunun yanında bireylerin yaşadığı yoksulluğun bir nevi derecesini gösteren ve bireyler arasında karşılaştırmaya olanak sağlayan yoksunluk endekslerini etkileyen faktörler incelendiğinde, endeksleri en fazla azaltan, yani bireyleri yoksulluklarından kurtulmalarına yardımcı olabilecek faktörler arasında; kadınların üniversite eğitimi almış, erkeklerin ise memur statüsünde çalışıyor olmaları gösterilebilir. Bunun yanında hem kadın hem de erkeklerin kendi kararlarını kendilerinin verebiliyor olmaları da, yoksunluğu azaltan unsurlar arasında belirtilebilir.

Görüldüğü üzere yaşanan bu tür yoksunlukları azaltmak ve yoksul bireylerin kabul edilebilir bir yaşam seviyesine sahip olmalarını sağlamak, birtakım sosyoekonomik politikaların varlığını zorunlu ve gerekli kılmaktadır. Yoksulların heterojen yapısını da göz önüne alan ve başta Mersin ve Erzurum örneklemleri olmak üzere, tüm ülkeyi kapsayan bir yoksullukla mücadele 
programının temel amacı, ekonomik büyüme yoluyla dolaylı olarak elde edilen kazançlar ile ayni ya da nakdi olarak sunulan doğrudan desteklerin ihtiyaç sahiplerine en etkin biçimde ulaş̧ırılıp, onların yaşam kalitelerinin artırılmasının sağlanmasıdır. Yoksulluğun türü ve derecesine göre değişiklik gösteren politikalar aile büyüklüğü, yaş, cinsiyet gibi faktörlere göre ayrışmaktadır, ki sonuçlardan görüldüğü üzere hem Mersin hem de Erzurum'da yaşanan yoksunluklar birbirinden oldukça farklılaşmıștır. Zira Mersin'de, gelir ve bireyin içinde bulunduğu durum nedeniyle utanmast ya da dişlanması boyutlarındaki yoksunluklar yoğun yaşanırken, Erzurum'da yine gelir yanında güçlenme boyutu yoksunluğu öne çıkmaktadır. Ancak sosyal yardım bağımlılığına karşı, çalışma hayatına çekilmesi amaçlanan bu yoksul kesimlerin kendi iç dinamiklerine göre politikaların oluşturulması, başarı olasılığını arttırmanın yanında, maliyetleri de bir üst basamağa taşıyabilmektedir. Uygulanan politikanın başarı olasılığının arttırılması ve maliyetlerin en aza indirilmesi ise; eş zamanlı olarak mülkiyet yapısı, işgücü piyasası, gelir dağılımı, eğitim, sağlı, güçlenme, fiziksel güvenlik, topluma kazandırma gibi alanlara ilişkin politika sepetinin oluşturulmasını gerekli kılmaktadır.

$\mathrm{Bu}$ politikalar doğrultusunda aktarılacak desteklerin doğru kişilere ulaştırılabilmesi için kapsamlı analizlerin yapılması, yoksul bireylere ait verilerin tek çatı altında toplanması ve hangi bireylerin, hangi göstergede yoksunluk yaşadıklarının tespiti kaçınılmaz olmaktadır. Bu bağlamda ve özellikle Mersin/Erzurum illerinin incelendiği bu çalışmadan elde edilen bulgular ışığında, yerel ölçekte ele alınacak politikaların Mersin'de gelir, utanma/dışlanmışlık hissetmeden yer alma ve fiziksel güvenlik; Erzurum'da ise gelir, güçlenme ve utanma/dışlanmışlık hissetmeden yer alma boyutlarına öncelik vermeleri, bu illerin yoksulluklarının azaltılmasında son derece önem arz etmektedir. Ayrıca, Mersin ve Erzurum özelinde ilköğretim ve altındaki eğitimlilerin, orta yaşlıların, emekçilerin ve özellikle de kadınların yoksunluğunun en aza indirilmesine yönelik adımların vakit kaybetmeden atılması da, bu kesimler için olmazsa olmazlar arasında belirtilebilir. Yakın geçmişte özellikle kadınların güçlenmelerine ve toplumda utanma/dışlanma hissetmeden yer almalarına yönelik politikalarda iyileştirmeler görülmektedir. $\mathrm{Bu}$ noktada kadınları ekonomik olarak güçlendirip, eşine bağımlı olmamasına olanak sağlayan mikro kredi uygulamaları bu iyileştirmeler arasında sayılabilir. Bu tür politikaların tanıtılması, yaygınlaştırılması ve tüm kesimlere ulaştırılması uygulamadan beklenen sonuçların başarısını olumlu yönde etkileyecektir. Bunlara ek olarak özellikle kadınların yoksunluğunu en fazla arttıran ve azaltan değişkenlerin parasal göstergelerden ziyade eğitim grubunun içinde yer alıyor olması, kadınların eğitim düzeylerinin önemi hakkında fikir verebilmektedir, ki uygulanacak politikalarda kadın eğitimine öncelik verilmesi, bireyin/hanenin yoksulluğunu azaltması yanında, bireylerin güçlenmesine de katkı sağlayacaktır. 
Son olarak, düzenli bir işte sürekli gelir elde edilmesinin ve bireyin kendi kararlarını kendi verebiliyor olmasının yoksunluk endekslerini azalttığı, eğitim düzeyi ile bu faktörler arasında ise aynı yönlü ilişki olduğu düşünüldüğünde, eğitime yapılan yatırımların yoksulluğu hem doğrudan hem de dolaylı olarak azaltabileceği açık bir şekilde kendini göstermektedir.

\section{Kaynakça}

Akder, Halis (2000). "Türkiye'de Bölgesel Eşitsizlikler ve Kırsal Yoksulluk”, Yoksulluk, TESEV Yayınları, 21, 15-36.

Alkire, Sabina (2007). "The Missing Dimensions Of Poverty Data: Introduction to The Special Issue", Oxford Development Studies, 35(4), 347-359

Alkire, Sabina ve James Foster (2007). Counting and Multidimensional Poverty Measurement, (Oxford Poverty and Human Development Initiative Working Paper Series No: 7), 1-33, OPHI Web Sitesinden Erişildi: https://ophi.org.uk/resources/ophi-working-papers/

Alkire, Sabina ve Suman Seth (2008). Measuring Multidimensional Poverty In India: A New Proposal, (Oxford Poverty And Human Development Initiative Working Paper Series No: 15), 1-49. OPHI Web Sitesinden Erişildi: https://ophi.org.uk/resources/ophi-working-papers/

Alkire, Sabina ve Maria Emma Santos (2010). "Acute Multidimensional Poverty: A New Index For Developing Countries", United Nations Development Programme Human Development Reports Research Paper 2010/11.

Alkire, Sabina ve James Foster (2011a). "Counting and Multidimensional Poverty Measurement", Journal Of Public Economics, 95(7-8), 476-487.

Alkire, Sabina ve James Foster (2011b). "Understanding And Misunderstanding Of Multidimensional Poverty Measurement", The Journal Of Economic Inequality, 9(2), 289-314

Battiston, Diego, Cruces Guillermo, Luis Lopez Calva, Maria Ana Lugo ve Maria E. Santos (2009). Income And Beyond: Multidimensional Poverty in Six Latin American Countries, (Oxford Poverty And Human Development Initiative Working Paper Series No: 17), OPHI Web Sitesinden Erişildi: https://ophi.org.uk/resources/ophi-working-papers/

Bourguignon, François ve Satya R. Chakravarty (2003). "The Measurement Of Multidimensional Poverty", Journal Of Economic Inequality, 1(1), 25-49.

Christopher, Bennett ve Shabana Mitra (2013). "Multidimensional Poverty: Measurement, Estimation, And Inference" Econometric Reviews, 32(1), 57-83.

Çıngı, Hülya (1994). Örnekleme Kuramı, Hacettepe Üniversitesi Fen Fakültesi Matbaası, Ankara.

Chakravarty Satya R. , Joseph Deutsch, ve Jacques Silber (2008). "On The Watts Multidimensional Poverty Index And Its Decomposition”, World Development, 36(6), 1067-1077.

Demir Şeker, Sırma (2011). "Türkiye'nin İnsani Gelişme Endeksi Ve Endeks Sıralamasının Analizi”, T.C. Kalkınma Bakanlığı Sosyal Sektörler Ve Koordinasyon Genel Müdürlüğü, 2828, Ankara.

Devlet Planlama Teşkilatı-DPT (1996). IIllerin Sosyo-Ekonomik Gelişmişlik Sıralaması Araştırması, DPT, (Haz. Dinçer B., Özaslan M. Ve Satılmış E.), 2466, Ankara. 
Devlet Planlama Teşkilatı-DPT (2003). IIllerin Ve Bölgelerin Sosyo-Ekonomik Gelişmişlik Sıralaması Araştırması, DPT, 2671, Ankara.

Eren, Aslan ve Ozan Bahar, (2004). "Yoksulluğa Kavramsal Bir Bakış: Dünya Ve Türkiye'deki Görünümü", Iktisat Işletme Ve Finans, 19(220), 36-50.

Foster, James, Joel Greer ve Erik Thorbecke (1984). "A Class of Decomposable Poverty Measures", Econometrica, 3(52), 761-766.

Gürsel, Seyfettin, Bülent Anıl ve Ayşenur Acar (2013). "Türkiye'de Yoksulluk Tartışması, Kim Haklı? Yoksulluk Arttı Mı, Azaldı Mı?" Bahçeşehir Üniversitesi Ekonomik Ve Toplumsal Araştırmalar Merkezi (BETAM), 13(153), İstanbul.

Günaydın, Faik Yücel, (2011). “Türkiye'de Hanehalkı İşücü Anketinden İşgücü Üzerine Gözlemler”, Ankara Üniversitesi Sosyal Bilimler Enstitüsü İktisat Anabilim Dalı Yayınlanmamış Yüksek Lisans Tezi, Ankara, 2011.

Hill, Carter, William E. Griffiths ve Guay C. Lim (2011). Principles Of Econometrics, (4th Ed), John Wiley And Sons Inc., New Jersey.

Kalkınma Bakanlığı, (2013). İlerin Ve Bölgelerin Sosyo-Ekonomik Gelişmişlik Sıralaması Araştırması (SEGE-2011), Bölgesel Gelişme Ve Yapısal Uyum Genel Müdürlüğü, Ankara.

Kroll Lars Eric, Maria Schumann, Jens Hoebel ve Thomas Lampert (2017) "Regional Health Differences-Developing a Socioeconomic Deprivation Index for Germany" Journal of Health Monitoring, 2(2), 98-114.

Macculi, Iris (2009). "Essay On Polarization, Multidimensional Poverty And Health-Related Effect: An Application to Switzerland", These De Doctorat: Universite Geneve, No. SES: 711, Geneve.

Mclennan, Davis, Helen Barnes, Michael Noble, Joanna Davies ve Elisabeth Garratt (2011). The English Indices of Deprivation 2010, Department for Communities and Local Government, London.

Oğuş, Ayla (2005). “Türkiye'de Gelir Dağıımı”, iktisat Işsletme Ve Finans, 20(236), 27-40.

Sen, Amartya (1976). "Poverty: An Ordinal Approach To Measurement”, Econometrica, 44(2), 219231.

Sen, Amartya (1982). "Rights And Agency", Philosophy And Public Affairs, 11(1), 3-39.

Sen, Amartya. (1983)." Poor, Relatively Speaking", Oxford Economic Papers, 35(2), 153-169.

Sen, Amartya (1997). "Editorial: Human Capital And Human Capability", World Development, Elsevier, 25(12), 1959-1961.

Sen, Amartya (1999). "Development As Freedom”, NY: Knopf Publishers, New York.

Sen, Amartya (2004). Capabilities, Lists, And Public Reason: Continuning The Conversation, Feminst Economics, 10(3), 77-80

Stapleton Connie D., (1997). "Basic Concepts And Procedures of Confirmatory Factor Analysis", The Annual Meeting of The Southwest Educational Research Association, Austin.

Tatıdil, Hüseyin (2002). Uygulamalı Çok Değişkenli Istatistiksel Analiz, Ziraat Matbaacılık, Ankara,

Türkiye İstatistik Kurumu. (2006-2007). Gelir Ve Yaşam Koşulları Araştırması 2006-2007 Ankara.

Türkiye İstatistik Kurumu-TÜiK. (2008). Gelir Ve Yaşam Koşulları Araştırması 2008, Ankara.

Türkiye İstatistik Kurumu-TÜiK. (2009). Gelir Ve Yaşam Koşulları Araştırması 2009, Ankara.

Türkiye İstatistik Kurumu-TÜiK. (2011). Gelir Ve Yaşam Koşulları Araştırması 2011, Ankara. 
Watson, Verity, Matt Sutton, Chris Dibben ve Mandy Ryan (2008). Deriving Weights for The Index of Multiple Deprivation Based on Societal Preferences: The Application of a Discrete Choice Experiment, (Oxford Poverty And Human Development Initiative Working Paper Series No: 24), OPHI Web Sitesinden Erişildi: https://ophi.org.uk/resources/ophi-working-papers/

World Bank, (2017), Index Of Multiple Deprivation, Conceptual Framework for Identifying Lagging Municipalities and Towns in Croatia, Republic of Croatia and World Bank Group, Republic of Croatia Web sitesinden Erişildi: https://razvoj.gov.hr/UserDocslmages//O\%20 ministarstvu/Regionalni\%20razvoj//ndex\%20of\%20Multiple\%20Deprivation\%20\%20Conceptual\%20framework_22_10_2018.pdf.

Yamane, Taro (2010). Temel Örnekleme Yöntemleri, (Çev. Esin A. vd.), Literatür Yayıncılık, Yayın No:53, İstanbul.

Zacharias, Ajit, Thomas Masterson ve Emel Memiş (2014). "The Levy Institute Measure Of Time And Consumption Poverty For Turkey", Levy Economics Institute Of Bard Collage, 46, New York.

Zanbak, M. (2014). "Yetenekler Yaklaşımı Perspektifi ile Yoksulluğun Ölçülmesi: Yoksulluğun Kayıp Boyutları Üzerine Ampirik Bir Uygulama", Akdeniz Üniversitesi Sosyal Bilimler Enstitüsü Yayımlanmamış Doktora Tezi, Antalya. 


\section{Ekler}

Ek 1: Mersin ve Erzurum Örneklemlerinin Tanımlayıcı İstatistikleri

\begin{tabular}{|c|c|c|c|c|}
\hline & & & Kişi & $\%$ \\
\hline \multirow{7}{*}{ Genel } & \multirow{3}{*}{ Mersin } & Örneklem & 1200 & 100,00 \\
\hline & & Hanede Yaşayan Ortalama Fert Sayısı & 3 & - \\
\hline & & Çocuksuz Hane Sayısı & 170 & 28,33 \\
\hline & & & & \\
\hline & \multirow{3}{*}{ Erzurum } & Örneklem & 1200 & 100,00 \\
\hline & & Hanede Yaşayan Ortalama Fert Sayısı & 4 & - \\
\hline & & Çocuksuz Hane Sayısı & 155 & 25,83 \\
\hline \multirow{5}{*}{ Cinsiyet } & \multirow{2}{*}{ Mersin } & Kadın & 600 & 50,00 \\
\hline & & Erkek & 600 & 50,00 \\
\hline & & & & \\
\hline & \multirow{2}{*}{ Erzurum } & Kadın & 600 & 50,00 \\
\hline & & Erkek & 600 & 50,00 \\
\hline \multirow{9}{*}{ Yaş } & \multirow{4}{*}{ Mersin } & $15-34$ & 541 & 45,08 \\
\hline & & $35-54$ & 563 & 46,92 \\
\hline & & $55+$ & 96 & 8,00 \\
\hline & & Yaş Ortalaması & 38 & - \\
\hline & & & & \\
\hline & \multirow{4}{*}{ Erzurum } & 15-34 & 630 & 52,50 \\
\hline & & $35-54$ & 444 & 37,00 \\
\hline & & $55+$ & 126 & 10,50 \\
\hline & & Yaş Ortalaması & 37 & - \\
\hline \multirow{9}{*}{ Eğitim } & \multirow{4}{*}{ Mersin } & Okuma-Yazma Bilmeyen & 22 & 1,83 \\
\hline & & İlköğretim & 386 & 32,17 \\
\hline & & Lise & 393 & 32,75 \\
\hline & & Üniversite ve üstü & 399 & 33,25 \\
\hline & & & & \\
\hline & \multirow{4}{*}{ Erzurum } & Okuma-Yazma Bilmeyen & 58 & 4,83 \\
\hline & & İlköğretim & 538 & 44,83 \\
\hline & & Lise & 287 & 23,92 \\
\hline & & Üniversite ve üstü & 317 & 26,42 \\
\hline \multirow{6}{*}{$\begin{array}{l}\text { Sosyoekonomik } \\
\text { Sinif }\end{array}$} & \multirow{6}{*}{ Mersin+Erzurum } & Kapitalist & 233 & 9,71 \\
\hline & & Kentli Profesyonel & 99 & 4,13 \\
\hline & & Küçük Burjuva & 98 & 4,08 \\
\hline & & Nitelikli Emekçi & 370 & 15,42 \\
\hline & & Emekçi & 481 & 20,04 \\
\hline & & Çalışmayan & 1119 & 46,62 \\
\hline
\end{tabular}


Ek 2: Yoksunluk Endeksinin Hesaplanmasinda Kullanılan Boyut ve Göstergeler (8 boyut, 58 gösterge)

\begin{tabular}{|c|c|c|c|c|c|c|c|}
\hline $\begin{array}{l}\text { ISTIHDAM-IŞ } \\
\text { YERi } \\
\text { GÜVENLIĞi } \\
8 \text { gösterge }\end{array}$ & $\begin{array}{l}\text { GELIRR } \\
2 \text { gösterge }\end{array}$ & $\begin{array}{l}\text { SAĞLIK } \\
5 \text { gösterge }\end{array}$ & $\begin{array}{l}\text { GÜÇLENME } \\
7 \text { gösterge }\end{array}$ & $\begin{array}{l}\text { UTANMA/ } \\
\text { DIŞLANMIŞLIK } \\
\text { HISSETMEDEN } \\
\text { YER ALMA } \\
8 \text { gösterge } \\
\end{array}$ & $\begin{array}{l}\text { YAŞAMSAL } \\
\text { ANLAM VE } \\
\text { DEĞER } \\
5 \text { gösterge }\end{array}$ & $\begin{array}{l}\text { FiZiKSEL } \\
\text { GÜVENLIK } \\
4 \text { gösterge }\end{array}$ & $\begin{array}{l}\text { HANENIN } \\
\text { SOSYO- } \\
\text { EKONOMIK } \\
\text { YAPISI } \\
3 \text { gösterge } \\
\end{array}$ \\
\hline $\begin{array}{l}\text { 1- İ̧̧ } \\
\text { güvencesi } \\
\text { 2- Hastalık izni } \\
\text { 3- Tatil } \\
\text { 4- Doğum izni } \\
\text { 5- Sigorta } \\
\text { 6- Fiziksel/ } \\
\text { zihinsel } \\
\text { koşullar } \\
\text { 7- Is kazası } \\
\text { 8- I̧/ortam } \\
\text { güvenliği } \\
\text { 8-1. Makina } \\
\text { güvenliği } \\
\text { 8-2. İ̧̧ } \\
\text { eldiveni } \\
\text { 8-3. Makina } \\
\text { gürültüsü } \\
\text { 8-4. Ortam } \\
\text { sıcaklığı } \\
\text { 8-5. Kimyasal } \\
\text { ya da gazlar } \\
\text { 8-6. Ağır yük/ } \\
\text { ayakta çalışma } \\
\text { 8-7. Kaymal } \\
\text { düşme }\end{array}$ & $\begin{array}{l}\text { 1-Tasarruf } \\
\text { 2- Borç }\end{array}$ & $\begin{array}{l}\text { 1- Sağlık } \\
\text { durumu } \\
\text { 2- Sosyal } \\
\text { sağlık sistemi } \\
\text { 3-5 yaş altı } \\
\text { çocuk } \\
\text { beslenmesi } \\
\text { 4- Hamile/ } \\
\text { emziren anne } \\
\text { beslenmesi } \\
\text { 5-Yaşlı } \\
\text { beslenmesi }\end{array}$ & $\begin{array}{l}\text { 1- Günlük } \\
\text { aktivite kararı } \\
\text { kontrolü } \\
\text { 2- Harcama } \\
\text { kararı kontrolü } \\
\text { 3- Sağlık kararı } \\
\text { kontrolü } \\
\text { 4- Şiddet/tehlike } \\
\text { kararı kontrolü } \\
\text { 5- Dini karar } \\
\text { kontrolü } \\
\text { 6- Iş hayatı } \\
\text { kararı kontrolü } \\
\text { 7- Özerklik }\end{array}$ & $\begin{array}{l}\text { 1- Yoksulluktan } \\
\text { utanma } \\
\text { 2- Aile } \\
\text { yoksulluğundan } \\
\text { utanma } \\
\text { 3- Toplumda } \\
\text { utanma, sıkılma } \\
\text { 4- Küçük düşme } \\
\text { 5- Dışlanma } \\
\text { 6- Adil davranış } \\
\text { 7- Etnik, dinsel ve } \\
\text { kültürel geçmişin } \\
\text { etkisi } \\
\text { 7-1. Kamu/altyapı } \\
\text { 7-2. Kamu } \\
\text { kurumlarında iş/ } \\
\text { sözleşme } \\
\text { 7-3. O̧zel sektörde } \\
\text { iss/sözleşme } \\
\text { 7-4. Kamusal } \\
\text { barınma } \\
\text { 7-5. Üniversite } \\
\text { öncesi eğitim } \\
\text { olanaklarından } \\
\text { faydalanma } \\
\text { 7-6. Üniversitede } \\
\text { eğitim } \\
\text { olanaklarından } \\
\text { faydalanma } \\
\text { 8- Ekonomik } \\
\text { geçmişin etkisi } \\
\text { 8-1. Kamu/altyapı } \\
\text { 8-2. Kamu } \\
\text { kurumlarında iş/ } \\
\text { sözleşme } \\
\text { 8-3. Özel sektörde } \\
\text { iş/sözleşme } \\
\text { 8-4. Kamusal } \\
\text { barınma } \\
\text { 8-5. Üniversite } \\
\text { öncesi eğitim } \\
\text { olanaklarından } \\
\text { faydalanma } \\
\text { 8-6. Üniversitede } \\
\text { eğitim } \\
\text { olanaklarından } \\
\text { faydalanma } \\
\end{array}$ & $\begin{array}{l}\text { 1- Özgürlük } \\
\text { 2- Barınma } \\
\text { memnuniyeti } \\
\text { 3- Fiziksel } \\
\text { güvenlik } \\
\text { memnuniyeti } \\
\text { 4- Eğitim } \\
\text { memnuniyeti } \\
\text { 5- Yaşamın } \\
\text { tamamından } \\
\text { memnuniyet }\end{array}$ & $\begin{array}{l}\text { 1- Hırsızlık } \\
\text { 2- Şiddet } \\
\text { 3- Gelecekte } \\
\text { şiddet olasilığı } \\
\text { 4- Güvenlik } \\
\text { seviyesi değişimi }\end{array}$ & $\begin{array}{l}\text { 1- İcme suyu } \\
\text { 2- Tuvalet } \\
\text { 3- Zemin }\end{array}$ \\
\hline
\end{tabular}


Ek 3: Yoksunluk Endeksinin Hesaplanmasında Kullanılan Göstergelerdeki Yoksunluk Şartları (Sinırları) ( 8 boyut, 58 gösterge)

\begin{tabular}{|c|c|c|c|c|c|c|c|}
\hline $\begin{array}{l}\text { ISTTHDAM-îs YERI } \\
\text { GÜVENLiĞi }\end{array}$ & GELIR & SAĞLIK & GÜÇLENME & $\begin{array}{l}\text { UTANMA/ } \\
\text { DISSLANMIŞLIK } \\
\text { HISSETMEDEN YER } \\
\text { ALMA }\end{array}$ & $\begin{array}{l}\text { YAŞAMSAL } \\
\text { ANLAM VE } \\
\text { DEGGER }\end{array}$ & $\begin{array}{l}\text { FiZiKSEL } \\
\text { GÜVENLiK }\end{array}$ & $\begin{array}{l}\text { HANENIN SOSYO- } \\
\text { EKONOMIK } \\
\text { YAPISI }\end{array}$ \\
\hline 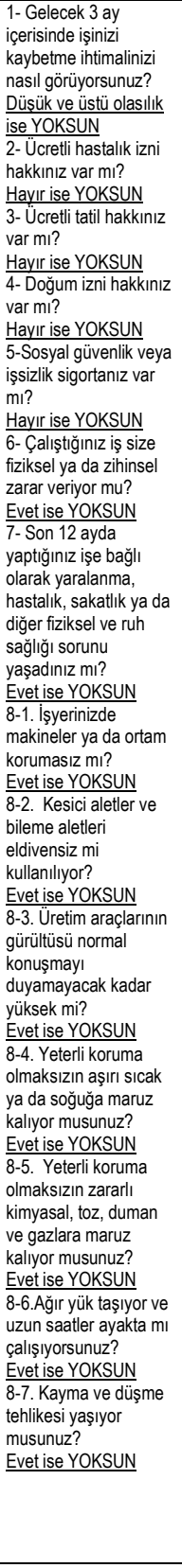 & $\begin{array}{l}\text { 1.Tasarrufunuz } \\
\text { var mı? } \\
\text { Hayıı ise } \\
\text { YOKSUN } \\
\text { 2.Borcunuz var } \\
\text { mı? } \\
\text { Evet ise } \\
\text { YOKSUN } \\
\end{array}$ & $\begin{array}{l}\text { 1- Şu anda sağlık } \\
\text { durumunuzu nasıl } \\
\text { tanımlarsını? } \\
\text { İi değil ise YOKSUN } \\
\text { 2- Herhangi bir Sosyal } \\
\text { sağlık sistemine dahil } \\
\text { misiniz? } \\
\text { Hayır ise YOKSUN } \\
3 \text { - Sizce } 5 \text { yaş altı } \\
\text { çocuklarınızın } \\
\text { beslenme durumu iyi } \\
\text { midir? } \\
\text { Hayır ise YOKSUN } \\
4 \text {.Hanehalkında varsa } \\
\text { hamile ve emziren } \\
\text { annelerin beslenme } \\
\text { durumu yeterli midir? } \\
\text { Hayır ise YOKSUN } \\
5-\text { Sizce } \\
\text { hanehalkından } 60 \text { yaş } \\
\text { ve üstü yaşIIların } \\
\text { beslenme durumu } \\
\text { yeterli midir? } \\
\text { Hayır ise YOKSUN }\end{array}$ & 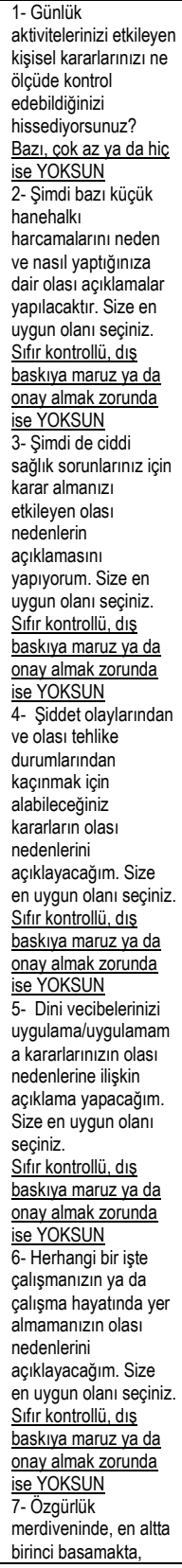 & 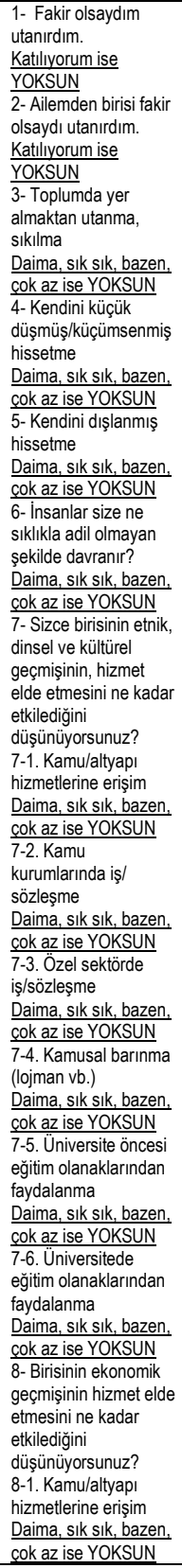 & $\begin{array}{l}\text { 1- Hayatımı } \\
\text { nasıl } \\
\text { yaşayacağım } \\
\text { konusunda } \\
\text { ozzgüüm. } \\
\text { Katımıyorum ise } \\
\text { YOKSUN } \\
\text { 2- Barınma } \\
\text { memnuniyeti } \\
\text { Memnun değil } \\
\frac{\text { ise YOKSUN }}{3-\text { Fiziksel }} \\
\text { güvenlik } \\
\text { memnuniyeti } \\
\text { Memnun değil } \\
\text { ise YOKSUN } \\
\text { - Eğitim } \\
\text { memnuniyeti } \\
\text { Memnun değil } \\
\text { ise YOKSUN } \\
\text { 5- Yaşamınızın } \\
\text { tamamindan } \\
\text { memnuniyet } \\
\text { Memnun değil } \\
\text { ise YOKSUN } \\
\end{array}$ & 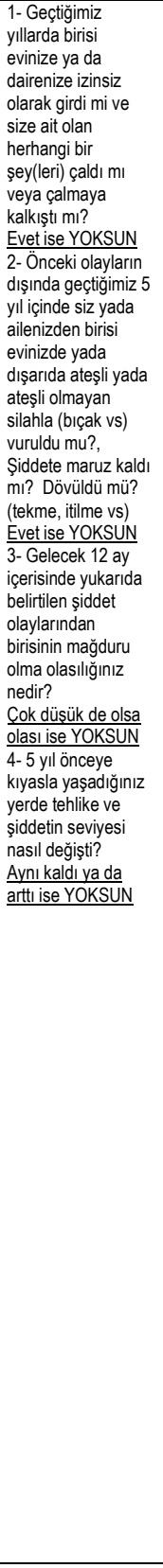 & $\begin{array}{l}\text { 1- Evde } \\
\text { kullandığınız içme } \\
\text { suyunun kaynağı } \\
\text { nedir? } \\
\text { Sebeke suyu ya da } \\
\frac{\text { damacana değilse }}{\text { YOKSUN }} \\
\text { 2- Tuvalet evin } \\
\text { içinde mi, dışında } \\
\text { mı? } \\
\text { Icinde değilse } \\
\text { YOKSUN } \\
\text { 3- Eviniz zemini ne } \\
\text { ile kaplıdır? } \\
\text { Toprak ya da beton } \\
\text { ise YOKSUN } \\
\end{array}$ \\
\hline
\end{tabular}


1340 • Ankara Üniversitesi SBF Dergisi • 75 (4)

\begin{tabular}{|c|c|}
\hline $\begin{array}{l}\text { kendi hayatlarına } \\
\text { ilişkin özgürce karar } \\
\text { veremeyen ve } \\
\text { hayatlarının gidişatı } \\
\text { üzerinde en ufak bir } \\
\text { kontrole sahip } \\
\text { olmayan kişilerin } \\
\text { olduğunu düşünün. } \\
\text { Altıncı ve son } \\
\text { basamakta bu konuda } \\
\text { en özgür ve en fazla } \\
\text { kontrol sahibi kişilerin } \\
\text { olduğunu varsayın. } \\
\text { Bugün hangi } \\
\text { basamaktasını?? } \\
3 \text { ve altı ise YOKSUN } \\
\end{array}$ & 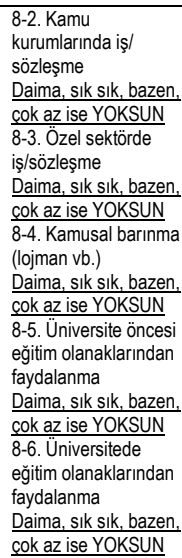 \\
\hline
\end{tabular}




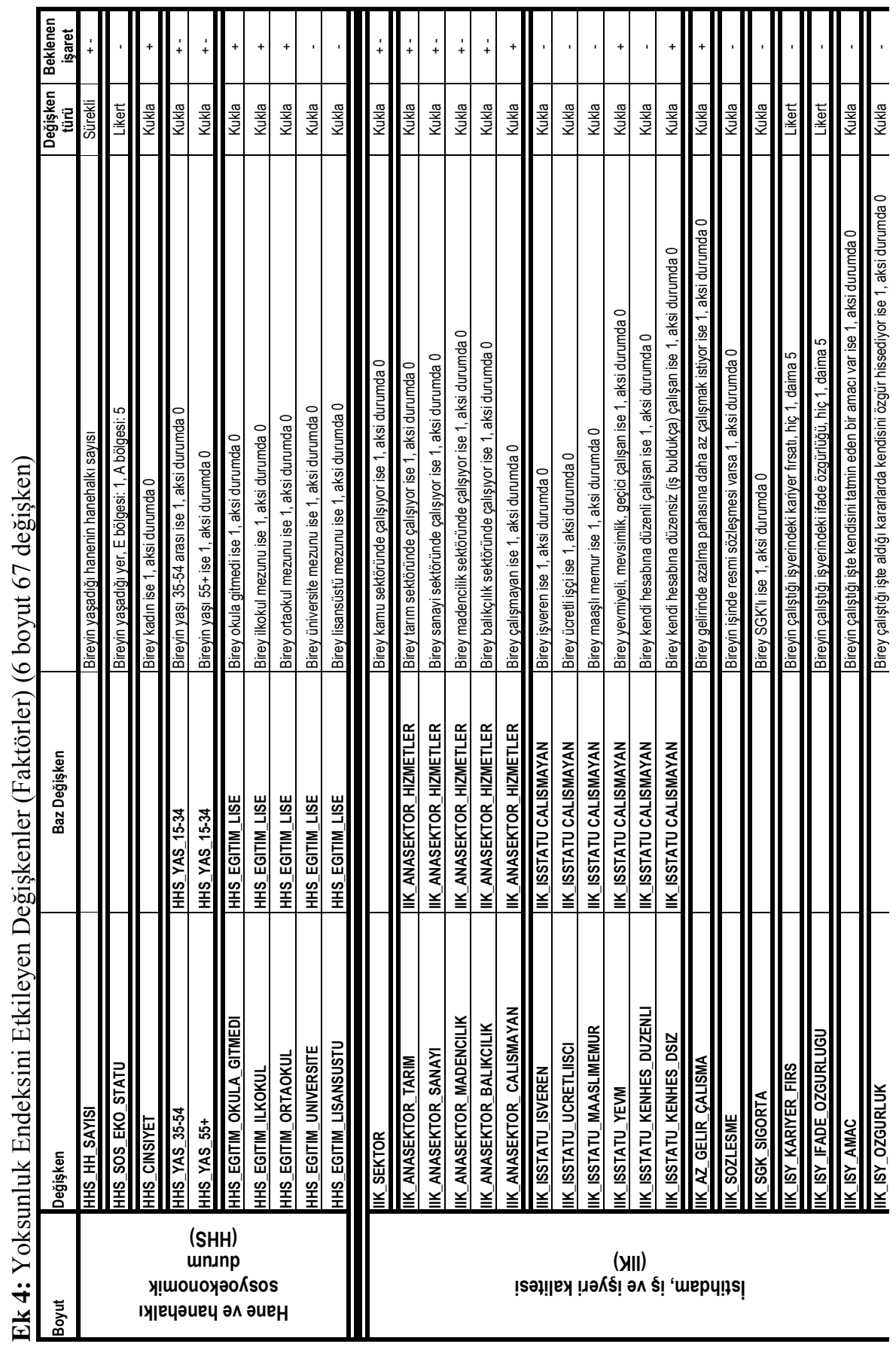




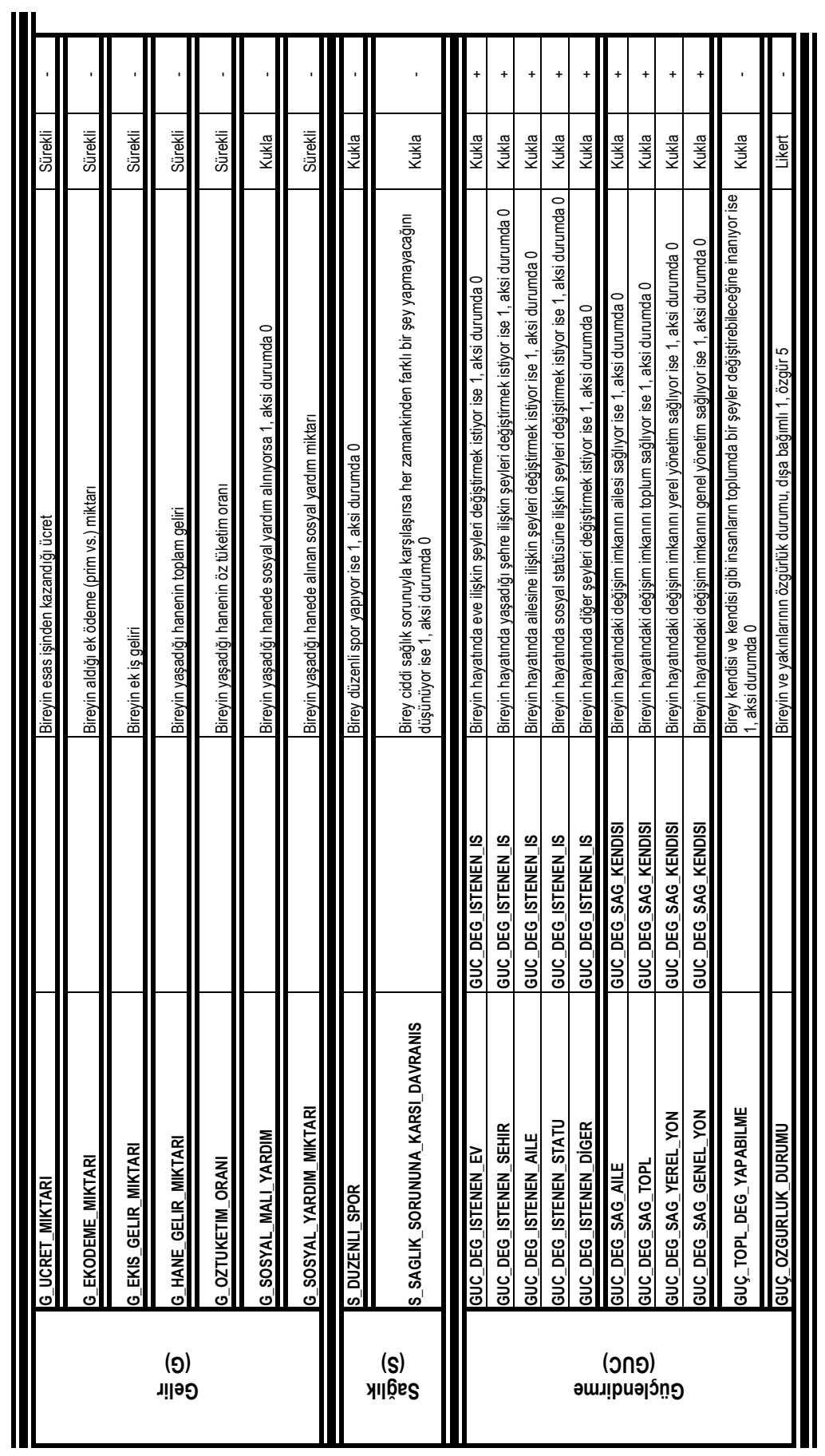




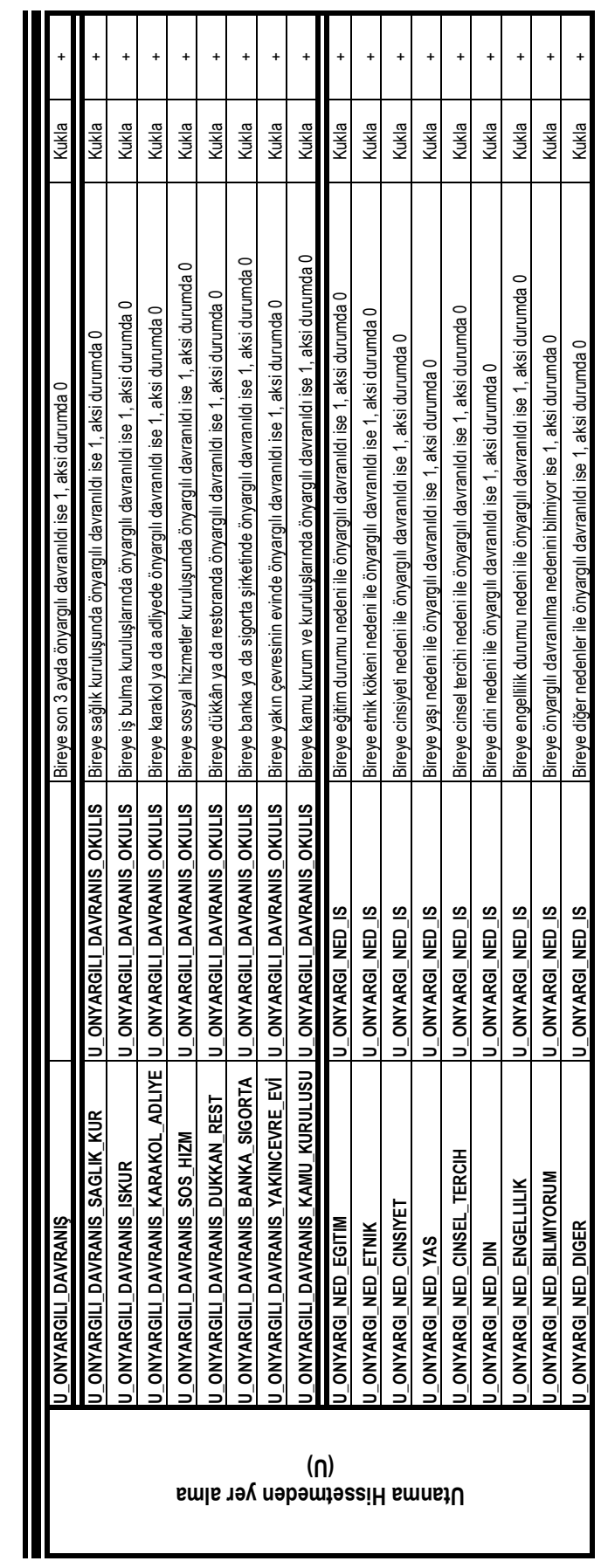


Ek 5: İstihdam, İş ve İşyeri Güvenliği ve Güçlendirme Boyutlarındaki Değişken Gruplarının Faktör Analizi Sonuçları

Ek 5.1: İstihdam, İş ve İşyeri Güvenliği Boyutundaki Değişken Grubunun KMO ve Barttlett Testleri

\begin{tabular}{llll}
\hline & & Mersin & Erzurum \\
\hline Örneklem Yeterliliğinin Kaiser-Meyer-Olkin Testi &, 684 &, 764 \\
\hline \multirow{2}{*}{ Bartlett Testleri } & Yaklaşık Ki-Kare & 535,265 & 389,272 \\
\cline { 2 - 4 } & Serbestlik Derecesi & 10 & 10 \\
\cline { 2 - 4 } & Sig. &, 000 &, 000 \\
\hline
\end{tabular}

Ek 5.2: İstihdam, İş ve İşyeri Güvenliği Boyutundaki Değişken Grubunun Bileşen Matrisi

\begin{tabular}{lllll}
\hline & \multicolumn{2}{l}{ Bileşen-Mersin } & \multicolumn{2}{l}{ Bileşen-Erzurum } \\
\hline & 1 & 2 & 1 & 2 \\
\hline IIK_ISY_OZGURLUK &, 807 &,- 232 &, 850 &,- 214 \\
\hline IIK_ISY_HAKSIZLIK &, 751 &,- 274 &, 825 &,- 252 \\
\hline IIK_ISY_SAYGI &,- 725 &, 260 &, 532 &, 415 \\
\hline IIK_KARIYER_FIRS &, 388 &, 738 &, 036 &, 775 \\
\hline IIK_ASTUST_ILISKI &, 496 &, 596 &, 200 &, 710 \\
\hline Extraction Methodu: Temel Bileşenler Analizi & & & & \\
\hline
\end{tabular}

Ek 5.3: Güçlendirme Boyutundaki Değişken Grubunun KMO ve Barttlett Testleri

\begin{tabular}{llll}
\hline & & Mersin & Erzurum \\
\hline Örneklem Yeterliliğinin Kaiser-Meyer-Olkin Testi &, 703 &, 725 \\
\hline \multirow{2}{*}{ Bartlett Testleri } & Yaklaşık Ki-Kare & 376,377 & 480,676 \\
\cline { 2 - 4 } & Serbestlik Derecesi & 3 & 3 \\
\cline { 2 - 4 } & Sig. &, 000 &, 000 \\
\hline
\end{tabular}

Ek 5.4: Güçlendirme Boyutundaki Değişken Grubunun Bileşen Matrisi

\begin{tabular}{lll}
\hline & Bileşen-Mersin & Bileşen-Erzurum \\
\hline GUC_OZGURLUK_DURUMU & 1 & 1 \\
\hline GUC_YAKIN_OZGURLUK_DURUMU &, 813 &, 863 \\
\hline GUC_10YILONCE_OZGURLUK_DURUMU &, 760 &, 752 \\
\hline Extraction Methodu: Temel Bileşenler Analizi & &, 592 \\
\hline
\end{tabular}


Ek 6: Birey Sınıf Pozisyonlarının Belirlenmesi

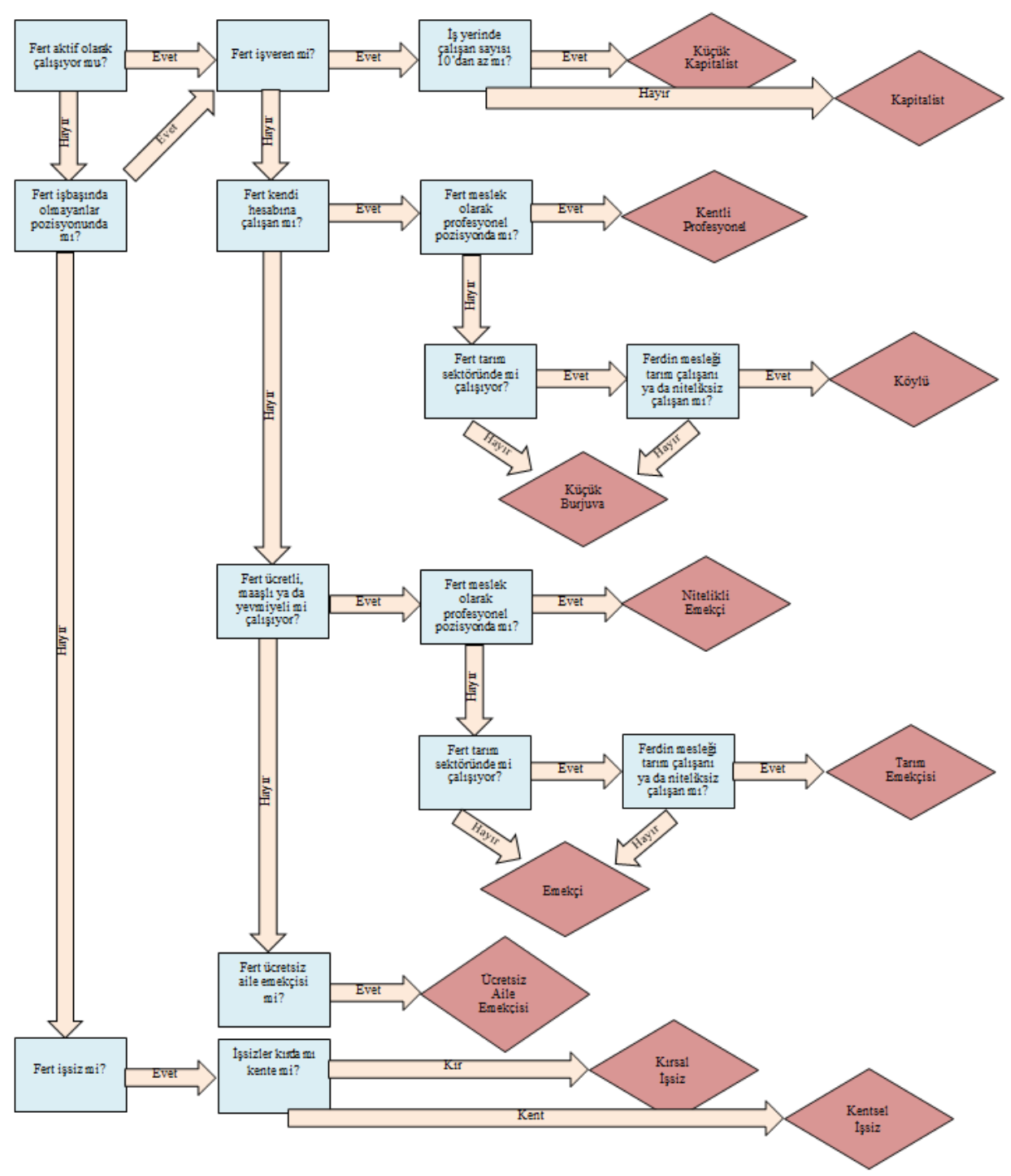

Not: Yukarıda yer alan şema, Günaydın (2011)'den yararlanılarak hazırlanmıştır. Bu çalışmada kullanılan anket sadece kentsel alanları kapsadığı için şemada görülen "köylü ve kırsal işsiz" sınıfları analizlerde göz ardı edilmiştir. 
Ek 7: Yoksunluk Endeksini Etkileyen Faktörlerin Tanımlayıcı İstatistikleri

\begin{tabular}{|c|c|c|c|c|c|c|c|c|c|c|c|}
\hline \multirow[t]{2}{*}{ MERSiN } & \multicolumn{5}{|c|}{ KADIN } & \multicolumn{5}{|c|}{ ERKEK } & \multirow{2}{*}{\begin{tabular}{|c|} 
Değisken \\
türü
\end{tabular}} \\
\hline & Ort. & Med. & Maks & $\operatorname{Min}$ & Std sapma & Ort. & Med. & Maks & $\operatorname{Min}$ & Std sapma & \\
\hline HHS_EGITIM_OKULA_GITMEDI & 0.02 & 0.00 & 1.00 & 0.00 & 0.15 & 0,01 & 0.00 & 1.00 & 0.00 & 0,11 & Kukla \\
\hline HHS_EGITIM_ILKOKUL & & & & & & 0,22 & 0.00 & 1.00 & 0.00 & 0,41 & Kukla \\
\hline HHS_EGITIM_UNIVERSITE & 0.30 & 0.00 & 1.00 & 0.00 & 0.45 & 0,33 & 0.00 & 1.00 & 0.00 & 0,47 & Kukla \\
\hline IIK_ISSTATU_ISVEREN & & & & & & 0,20 & 0.00 & 1.00 & 0.00 & 0,40 & Kukla \\
\hline IIK_ISSTATU_MAASLIMEMUR & & & & & & 0,16 & 0.00 & 1.00 & 0.00 & 0,37 & Kukla \\
\hline IIK_ISSTATU_UCRETLIISCI & 0.11 & 0.00 & 1.00 & 0.00 & 0.32 & & & & & & Kukla \\
\hline IIK_ISSTATU_YEVM & 0.006 & 0.00 & 1.00 & 0.00 & 0.08 & & & & & & Kukla \\
\hline IIK_KENHES_DSIZ & 0.005 & 0.00 & 1.00 & 0.00 & 0.07 & & & & & & Kukla \\
\hline III_SOZLESME & & & & & & 0,29 & 0.00 & 1.00 & 0.00 & 0,45 & Kukla \\
\hline IIK_ISY_KARIYER_FIRS & & & & & & 4,03 & 4,00 & 5,00 & 2,00 & 0,76 & Likert \\
\hline IIK_ISY_IFADE_OZGURLUGU & & & & & & 4,53 & 5,00 & 5,00 & 2,00 & 0,71 & Likert \\
\hline G_HANE_GELIR_MIKTARI & 788 & 0,00 & 10.000 & 0,00 & 1.459 & 1.652 & 1.450 & 12.000 & 0,00 & 1.669 & Sürekli \\
\hline G_SOSYAL_YARDIM_MIKTARI & 0,08 & 0,00 & 50,00 & 0,00 & 2,04 & & & & & & Sürekli \\
\hline S_DUZENLI_SPOR & 0,67 & 1,00 & 1.00 & 0.00 & 0,47 & 0,61 & 1,00 & 1,00 & 0,00 & 0,48 & Kukla \\
\hline GUC_DEG_ISTENEN_AILE & & & & & & 0,006 & 0,00 & 1,00 & 0,00 & 0,08 & Kukla \\
\hline GUC_DEG_ISTENEN_STATU & & & & & & 0,08 & 0,00 & 1,00 & 0,00 & 0,27 & Kukla \\
\hline GUC_DEG_SAG_AlLE & & & & & & 0,11 & 0,00 & 1,00 & 0,00 & 0,31 & Kukla \\
\hline GUC_DEG_SAG_TOPL & 0,03 & 0,00 & 1,00 & 0,00 & 0,18 & 0,02 & 0,00 & 1,00 & 0,00 & 0,16 & Kukla \\
\hline GUC_TOPL_DEG_YAPABILME & & & & & & 0,74 & 1,00 & 1,00 & 1,00 & 0,43 & Kukla \\
\hline GUC_OZGURLUK_DURUMU & 3.295 & 3,00 & 5,00 & 1,00 & 0,75 & 3,47 & 4,00 & 5,00 & 1,00 & 0,72 & Likert \\
\hline U_ONYARGILI_DAVRANIS & 0,08 & 0.00 & 1.00 & 0.00 & 0,27 & 0,01 & 0,00 & 1,00 & 0,00 & 0,09 & Kukla \\
\hline U_ONYARGI_NED_CINSIYET & 0,001 & 0.00 & 1.00 & 0.00 & 0,04 & & & & & & Kukla \\
\hline U_ONYARGI_NED_ETNIK & & & & & & & & & & & Kukla \\
\hline \multirow[t]{2}{*}{ ERZURUM } & \multicolumn{5}{|c|}{ KADIN } & \multicolumn{5}{|c|}{ ERKEK } & $\begin{array}{c}\text { Değisken } \\
\text { türü }\end{array}$ \\
\hline & Ort. & Med. & Maks & Min & Std sapma & Ort. & Med. & Maks & $\operatorname{Min}$ & Std sapma & \\
\hline HHS_HH_SAYISI & & & & & & 3,71 & 4,00 & 10,00 & 2,00 & 1,48 & Sürekli \\
\hline HHS_EGITIM_OKULA_GITMEDI & 0,07 & 0.00 & 1.00 & 0.00 & 0,26 & & & & & & Kukla \\
\hline HHS_EGITIM_UNIVERSITE & & & & & & 0,37 & 0,00 & 1,00 & 0,00 & 0,48 & Kukla \\
\hline III_AZ_GELIR_CALISMA & & & & & & 0,09 & 0,00 & 1,00 & 0,00 & 0,28 & Kukla \\
\hline IIK_ISSTATU_UCRETLIISCI & 0,01 & 0.00 & 1.00 & 0.00 & 0,12 & 0,37 & 0,00 & 1,00 & 0,00 & 0,48 & Kukla \\
\hline IIK_KENHES_DSIZ & 0,001 & 0.00 & 1.00 & 0.00 & 0,04 & & & & & & Kukla \\
\hline IIK_ISY_IFADE_OZGURLUGU & & & & & & 4,51 & 5,00 & 5,00 & 1,00 & 0,83 & Likert \\
\hline G_UCRET_MIKTARI & & & & & & 1,674 & 1.400 & 40.000 & 0,00 & 2.037 & Sürekli \\
\hline S_DUZENLI_SPOR & 0,64 & 1,00 & 1,00 & 0,00 & 0,47 & & & & & & Kukla \\
\hline GUC_DEG_SAG_AILE & 0,19 & 0,00 & 1,00 & 0,00 & 0,39 & 0,10 & 0.00 & 1.00 & 0.00 & 0,30 & Kukla \\
\hline GUC_DEG_SAG_TOPL & 0,01 & 0,00 & 1,00 & 0,00 & 0,12 & & & & & & Kukla \\
\hline GUC_TOPL_DEG_YAPABILME & 0,59 & 1,00 & 1,00 & 0,00 & 0,49 & 0,59 & 1,00 & 1,00 & 0,00 & & Kukla \\
\hline GUC_OZGURLUK_DURUMU & 3,01 & 3,00 & 5,00 & 1,00 & 1,03 & 3,20 & 3,00 & 5,00 & 1,00 & 1,05 & Likert \\
\hline U_ONYARGILI_DAVRANIS & & & & & & 0,08 & 0,00 & 1,00 & 0,00 & 0,28 & Kukla \\
\hline U_ONYARGI_NED_ETNIK & 0,01 & 0,00 & 1,00 & 0,00 & 0,10 & & & & & & Kukla \\
\hline U_ONYARGI_NED_CINSIYET & 0,005 & 0,00 & 1,00 & 0,00 & 0,07 & & & & & & Kukla \\
\hline
\end{tabular}

Bu tabloda sadece istatistiki olarak anlamlı çıkan göstergelere ait tanımlayıcı istatistikler yer almaktadır. Herhangi bir göstergeye ait tanımlayıcı istatistik değerinin olmaması, o il veya cinsiyette söz konusu göstergenin istatistiki olarak anlamsızlığın ifade etmektedir. 